\title{
A Study on the Influence of Synoptic-Scale Flows on Sea Breeze During Wintertime in the Coastal Zone Near Visakhapatnam, India
}

N.V.P. Kiran Kumar ( $\nabla$ kirannvp@gmail.com )

Vikram Sarabhai Space Centre

K. Jagadeesh

Sri Vasavi Engineering College

K. Niranjan

Andhra University

\section{Research Article}

Keywords: influence, synoptic-scale, sea, wintertime, coastal zone, Visakhapatnam, statistical results, airpollution dispersal, evolution

Posted Date: January 17th, 2022

DOI: https://doi.org/10.21203/rs.3.rs-1128041/v1

License: (a) (1) This work is licensed under a Creative Commons Attribution 4.0 International License. Read Full License 


\title{
A study on the influence of synoptic-scale flows on sea breeze during wintertime
} in the coastal zone near Visakhapatnam, India

\author{
N.V.P. Kiran Kumar ${ }^{1 *}$, K. Jagadeesh ${ }^{2}$ and K. Niranjan ${ }^{3}$ \\ 1) Space Physics Laboratory, Vikram Sarabhai Space Centre, Thiruvananthapuram, Kerala, 695022 \\ 2) Sri Vasavi Engineering College, Tadepalligudem, Andhra Pradesh, 534101 \\ 3) Department of Physics, Andhra University, Visakhapatnam, Andhra Pradesh, 530003 \\ *Email: kirannvp@gmail.com
}

\section{Abstract}

The present study focuses on the influence of prevailing winds (like onshore, offshore and alongshore) on sea breeze flow over the coastal station Visakhapatnam $\left(17.7^{\circ} \mathrm{N}, 83.3^{\circ} \mathrm{E}\right)$. The database consists of sodar observation relative to 58 sea breeze occurred during the winter season (December 2011-February 2012). Results show that the strength of sea breeze are modulated by the large-scale wind flow and show substantial changes between offshore, along-shore and onshore. The role of thermal forcing on the breeze circulation was investigated. Results show that temperature difference between land and sea $(\Delta \mathrm{T})$ is larger for offshore and along-shore when compared to that of onshore flow. Results reveal that the vertical velocities show downdrafts and updrafts just before and after the onset of sea breeze. The depth of sea breeze is found to be higher $(\sim 220 \mathrm{~m})$ for the offshore than onshore large scale circulation $(\sim 160 \mathrm{~m})$. It is found that offshore and alongshore favours the delayed arrival of sea breeze compared to that of onshore. The statistical analysis of sea breeze circulation addressed in this work highlight the distinct behavior in the structure and evolution of sea breeze using high temporal and vertical resolution of sodar observations under different synoptic-scale wind flow. Such statistical results are sparse over the industrialised coastal zones like Visakhapatnam where air pollution is a major concern, as well as for better understanding on the vertical mixing of aerosols and trace gases, and air-pollution dispersal. 
Over the coastal regions, the evolution of the atmospheric boundary layer (ABL) is significantly modulated by the mesoscale circulation systems like land/sea breeze (Simpson et al. 1977). In general, sea breeze are controlled by differences in the sea surface temperature (SST) and land surface air temperature, which is proportional to the pressure difference. Studies have shown that the strength and onset of sea breeze with varies geographical location, depends on several factors such as shape of the coastline, cloud cover, thermal forcing, large-scale wind flow, soil moisture, solar radiation, (Steyn and Kallos 1992; Stull 1998; Miller et al. 2003; Gilliam et al. 2004; Davis et al. 2020). Observations carried out over other coastal locations have shown that the onset of sea breeze (early/delay/normal) depends not only on prevailing background synoptic large-scale winds (like onshore flow, along-shore flow and offshore flow) but also on thermal forcing (e.g., Molina and Chen 2009; Federico et al. 2010).

Associated with the advection of sea breeze, the thermal structure of convective ABL (CABL) is modified with the formation of the thermal internal boundary layer (TIBL) (Kunhikrishnan et al. 1993; Rao and Fuelberg 2000; Anurose et al. 2016). Under weak synoptic-scale wind flow (onshore/offshore) conditions, the evolution of $\mathrm{CABL}$ over the coastal region attains peak around noontime with relatively lower CABL heights compared to that of the inland regions (Miller et al. 2003). However, studies have shown that the growth of coastal CABL is controlled by the offshore/onshore flow, the height of CABL are comparable with that of continental regions especially during offshore flow when compared to the onshore flow (Davis et al. 2021). With the passage of sea breeze front, an abrupt transition in the velocity and wind direction within the CABL were reported (Helmis 1987; Chiba 1993; Chiba 1997). The vertical velocities (updraft/downdraft) generated before and after the passage of sea breeze can initiate the development of convective clouds (e.g., Atkins et al. 1995). Also, vertical velocities play a crucial role in diluting the pollutants within the CABL, and quantitative analysis on these are of interest to the air-pollution meteorologists especially the vertical velocities associated by the sea breeze front. However, the magnitude of the vertical velocities and evolution of CABL are controlled by the strength and direction of the sea breeze (Helmis et al. 1987).

The intensity and vertical structure of sea breeze have a profound impact on the increased levels of air pollutants dispersal and the possibility of the re-circulation of pollutant gases by industries near the coastal site (e.g., Kitada 1987; Asimakopoulos et al. 1992; Krishna Moorthy et al. 2003; Niranjan et al. 2004; Augustin et al. 2020). 
The role of prevailing background large-scale synoptic wind flow on the evolution of sea breeze structure, its progression and cessation has been studied using numerical models and experimental studies (Estoque 1962; Simpson et al. 1977; Atkins and Wakimoto 1997; Miller et al. 2003; Gilliam et al. 2004; Molina and Chen 2009; Bajamgnigni and Steyn 2012; Grachev et al. 2018). Several researchers have reported on the influence of the synoptic flow on the sea breeze flow using sodar observations (Finkelstein et al. 1986; Zhong and Takle 1992; Mastrantonio et al. 1994; Helmis et al. 1995; Chiba 1997; Melas et al. 1998; Kalogiros et al. 1999; Menut et al. 1999; Puygrenier et al. 2005; Federico et al. 2010; Crosman and Horel 2010; 2016).

Over the Indian sub-continent, studies on the sea breeze circulation using Doppler sodar and tower-based measurements (Rao et al. 1981; Singal et al. 1986; Prakash et al. 1992; Kunhikrishnan et al. 1993; Gera and Saxena 1996; Prabha et al. 2002). Recently, using surface-based observations over the coastal station, Visakhapatnam, Kirankumar et al. (2019) highlighted the impact of background prevailing wind flow on the sea breeze characteristics such as occurrence, onset and cessation during different seasons over the site. What is relatively less known over this region is the dynamics (such as vertical velocities, the intensity of wind speed and sea breeze component, depth of sea breeze) within the vertical structure of the sea breeze circulation. This is due to the lack of database with a high temporal and vertical resolution concerning the growth and evolution of sea breeze associated with the prevailing synoptic-scale wind flow. Thus, the aim of the present study is to address this gap and quantify the characteristics of the sea breeze circulation during contrasting synoptic-scale wind flow conditions during the winter season 2011-12. This is carried out using the vertical profiles of Doppler sodar installed over the experimental site Visakhapatnam $\left(17.7^{\circ} \mathrm{N}, 83.3^{\circ} \mathrm{E} ; 20 \mathrm{msl}\right)$. Due to the lack of collocated surface based meteorological data, surface air temperature at 2m, SST were obtained from the ERA Interim reanalysis (Section 3.2).

The present study has significant implications in the studies related to the air pollution, diffusion of trace gases and aerosols etc. Section 2 presents the details on experimental site, instrumentation and database. Section 3 , presents the results and discussion on the influence of synoptic-scale winds on the sea breeze by considering three case studies (offshore, alongshore and onshore). A thorough statistical analysis of the phenomena is also presented in this section. Such studies have profound applications and can be useful, for example, addressing the near-surface and vertical distribution of aerosols, and air pollutant dispersal, helpful for the installation of wind power generators in the area and for mitigation measures of the heat island on the coastal town of Visakhapatnam. 


\section{Experimental site and background meteorological conditions}

The experimental site is located in the Department of Physics, Andhra University, Visakhapatnam which is $\sim 600 \mathrm{~m}$ from the eastern coast of the Bay-of-Bengal with the coastline roughly aligned to $45^{0}$ to $225^{\circ}$ (Fig. 1). Thus, breezes arriving at an angle between $45^{\circ}$ and $225^{\circ}$ are considered as sea breeze and the breezes flowing in other directions are considered as land-breeze (more details on wind flow regimes are presented in section 2.1.1). Hills with an elevation in the range of $500-1200 \mathrm{~m}$ are located at $\sim 30-50 \mathrm{~km}$ northwest of the experimental site. In general, fair-weather conditions with absence of large scale convection prevails during the winter seasons (December to February) and calm winds with dominant northerly/northeasterly prevail during this season. Figure 2 shows the synoptic mean wind pattern at $-850 \mathrm{hPa}$ level during winter seasons over the study region (marked with the ' $\star$ '), obtained from the ERA-Interim Reanalysis (Dee at al. 2011) data. From Fig. 2, it is evident that

100 the prevailing wind intensity is low $\left(<1 \mathrm{~ms}^{-1}\right)$ and pre-dominantly northerly/northeasterly during winter seasons.

\subsection{Instrumentation, data, method of analysis}

The acoustic sounder or SODAR (Sound Detection And Ranging) is a powerful tool for studying the microscale turbulence processes undergoing within the lower atmosphere. The Doppler sodar has the advantage of

104 probing the lower atmosphere with fine temporal and spatial resolution. The monostatic phased-array Doppler sodar system (Make: SAMEER, India) installed at Visakhapatnam can be operated at $1700-2500 \mathrm{~Hz}$ with a peak acoustic power of $100 \mathrm{~W}$. This sodar system consisting of an $8 \times 8$ array of 52 antenna elements made with piezoelectric transducers. The antenna is used for both transmitting and receiving the signals. Three moments, namely, signal strength, weighted mean Doppler shift, and half-width parameters of the power spectrum are estimated following adaptive moments estimation technique developed for sodar by Anadan et al. (2008). For the

110 present study, the sodar system was operated at a frequency of $1800 \mathrm{~Hz}$, range resolution of $20 \mathrm{~m}$, and inter-pulse

111 period of 6 seconds for probing up to $1000 \mathrm{~m}$. The frequency resolution of discrete frequency spectra is $8.33 \mathrm{~Hz}$.

112 Important specifications of the phased array Doppler sodar are given in Table 1.

113 Sodar observations during the winter season (December 2011-February 2012) forms the primary database for

114 this study. The data quality is assessed from the signal to noise ratio (SNR) of the sodar signal; the SNR is very

115 poor and irregular during precipitation. The absence of precipitation ensures good data quality during most of the

116 winter period. Extreme care has been taken in the quality check i.e. data recorded during isolated precipitation

117 events, overcast days and incomplete sea breeze circulation days are discarded. The data with a signal to noise

118 ratio (SNR) of $>1 \mathrm{~dB}$ only are considered for deriving the 3-dimensional winds in the present study. This criterion

119 generally limits the upper altitude height of the sodar observation of winds to $<260 \mathrm{~m}$ during most of the day. 
120 Altitude profiles of the zonal $(u)$, meridional $(v)$, vertical $(w)$ winds and SNR derived from the individual

121 soundings (once in 6 seconds) are further averaged for 10 minutes to improve the SNR. Finally, based on the

122 quality of the sodar data, 58 sea breeze days were considered for further analysis.

\section{$123 \quad$ 2.1.1 Synoptic flow regime classification}

124 Due to the variation in the intensity of the synoptic-scale winds and discontinuity in the terrain features 125 (coastal station), the turbulent characteristics of the sea breeze also changes. Following Molina and Chen (2009), 126 in the present study, daily winds derived from the ERA reanalysis at $850 \mathrm{hPa}$ data, were considered as a representative of the low-level synoptic-scale flow regimes to understand the variations in the sea breeze turbulent

128 characteristics associated with the synoptic-scale flow. Referring to the local coastline orientation (Fig.1), analyses have been done on the three different sets of data classified according to the wind direction as a) offshore wind

130 clockwise $\left(240.0^{\circ}-30.0^{\circ}\right)$ represents synoptic flow from land to sea, b) onshore wind $\left(60.0^{\circ}-\right.$ $\left.131210.0^{\circ}\right)$ representing the wind flow from sea to land, and c) alongshore wind $\left(30.0^{\circ}-60.0^{\circ}\right)(\mathrm{NE})$ and $\left(210.0^{\circ}-\right.$ $\left.132240.0^{\circ}\right)(\mathrm{SW})$

\section{$133 \quad$ 2.1.2. Identification of onset of sea breeze}

134 As specified in Section 2, the Visakhapatnam coastal line is stretched along the direction of $45^{\circ}-225^{\circ}$. The wind component normal to the coast is represented as the sea breeze component (SBC) and the following relation is used for the estimation of SBC.

$$
S B C=W S *(\sin 225-W D)
$$

138 Where $W S=\sqrt{u^{2}+v^{2}}$

$139 u$ - zonal wind $\left(\mathrm{ms}^{-1}\right) ; v$ - meridional wind $\left(\mathrm{ms}^{-1}\right)$ and WD $\left(^{0}\right)$ is the wind direction. WS $\left(\mathrm{ms}^{-1}\right)$ is the horizontal 140 wind speed, the positive SBC $\left(\mathrm{m} \mathrm{s}^{-1}\right)$ represents the sea breeze and the negative values represent land breeze.

141 Various sea breeze criteria were suggested to identify the sea breeze events (Furberg et al. 2002; Steyn and 142 Kallos 1992; Borne et al. 1998; Porson et al. 2007; Molina and Chen 2009). In this study, we adopted an objective 143 selection method as described in Kirankumar et al. (2019) for the identification of onset and cessation of the sea 144 breeze. (i) The sea breeze onset is identified by a distinct shift in the direction of wind across-coast from offshore 145 to onshore. Most importantly, the onshore wind component should last for more than 4 hours (Top panel in 146 Supplementary Material Fig. S.1). (ii) The onset of the sea breeze can also be identified by the change of sign of 147 SBC from negative (offshore) to positive (onshore) (marked by an upward arrow in the bottom panel of Fig. S.1).

148 (iii) The cessation of sea breeze happens when wind direction shifts from onshore to offshore i.e. the sign of SBC 149 shifts from positive (onshore) to negative (offshore) and this continues for more than 4 hours. 


\section{Results and discussion}

\subsection{Distribution of winds}

Figure 3 shows the wind rose plots recorded from ERA-Interim reanalysis $850 \mathrm{hPa}$ represents the large-scale circulation above the sea breeze circulation. The result shows rather widespread in the wind direction, i.e., about 74\%, $7.5 \%$ and 18.5\%, winds come from offshore, alongshore and onshore respectively (Fig. 3a). Besides the expected higher wind speed at $850 \mathrm{hPa}$, there is no distinct shift in the wind direction between the daytime and night-time observations (Figs. 3b, c).

Although wind data from the sodar is available at different height levels, to present the statistics of the winds near the surface $60 \mathrm{~m}$ data was considered (Figs. 3d-f). The frequency distribution of the seasonal wind observations from sodar at $60 \mathrm{~m}$ illustrates the surface coastal flow regime. The winds with low magnitude $(<4$ $\left.\mathrm{ms}^{-1}\right)$ distributed mostly in the NW-N direction, whereas the distribution of relatively high wind speed $\left(>4 \mathrm{~ms}^{-}\right.$ $\left.{ }^{1}\right)$ spread rather wide in the wind direction NE-E-SE (Fig. 3d). Out of the total observed seasonal wind, the frequency distribution of offshore and onshore winds is $62 \%$ and $25 \%$, respectively, and remaining $13 \%$ is distributed along the coastal line with $12 \% \mathrm{NE}$ and $1 \% \mathrm{SW}$ winds. During the daytime, the winds are high (>4 $\mathrm{ms}^{-1}$ ) and predominantly NE-E-SE-S with rather widespread. The enhancement in the frequency distribution of onshore winds (49\%) during the daytime shows the presence of the sea breeze (Fig. 3e). Noteworthy to mention here, the distribution of offshore winds (33\%) indicates the continuance of land breeze due to the delay in the onset of the sea breeze. Remaining $18 \%$ of daytime wind flow is distributed along the coastline with $16 \%$ from $\mathrm{NE}$ and $2 \%$ from SW. During the night, the winds are low $\left(<4 \mathrm{~ms}^{-1}\right)$ and predominantly NW-N-NE. The enhancement in the probability of occurrence of northerly winds suggests the dominance of offshore winds (91\%) during the night-time. Remaining 9\% of night-time wind flow is distributed between the alongshore (8\% (NE)) and $1 \%$ onshore winds.

The comparison of wind distribution between ERA at $850 \mathrm{hPa}$ and sodar at $60 \mathrm{~m}$ confirms the difference between the circulation at the surface and at the levels above the sea breeze and demonstrates the significance of the local circulations. Following are the important main outcomes: i) The dominance of onshore winds during the daytime and offshore winds during the night-time is well discernible in the sodar data while at $850 \mathrm{hPa}$ the wind direction is rather more spread; b) The daytime onshore wind due to the sea breeze is much more frequent at the surface ( $49 \%$ and $19 \%$ at the surface and at $850 \mathrm{hPa}$ respectively); c) The night-time offshore winds due to land breeze, are dominant at the surface ( $91 \%$ and $70 \%$ at the surface and at $850 \mathrm{hPa}$ respectively); d) as expected, higher wind speeds are observed at $850 \mathrm{hPa}$ than the surface. 
Figure 4 shows the time of onset of sea breeze and its frequency of occurrence under different synoptic conditions during the winter season (December 2011 to February 2012). For this, sodar observations at $60 \mathrm{~m}$ height level are considered. From the Fig.4, it can be seen that onset of the time of onset of sea breeze can occur as early as 08:00 IST (IST=GMT+05:30 hrs) and as late as 13:00 IST and most probable time of onset of the sea breeze is in between 09:30 and 10:30 IST (Fig.4b). The present results are in accord with the earlier studies by Sivaramakrishnan and Prakash Rao (1989) and Kirankumar et al. (2019).

Temperature differences between land and sea plays a crucial role in controlling the onset/cessation of sea breeze under weak synoptic-scale wind conditions. Figure 5 shows the mean difference between the sea surface temperature (SST) and surface air temperature observed at $(2 \mathrm{~m})$ close to the experimental site under different synoptic wind conditions during December 2011-February 2012. To study the land-ocean temperature contrast, air temperature (at $2 \mathrm{~m}$ ) over land and SST over the adjoining Bay of Bengal were obtained from ERA Interim Reanalysis (Dee et al. 2011) data with a temporal resolution of 1 hour and grid resolution of $0.25^{\circ} \times 0.25^{\circ}$. Extreme care has been taken in identifying the locations which are closest to the experimental site i.e. over the land $\left(17.75^{\circ} \mathrm{N}, 83.0^{\circ} \mathrm{E}\right)$ and over the ocean $\left(17.5^{\circ} \mathrm{N}, 83.25^{\circ} \mathrm{E}\right)$. The days considered to generate Fig. 5 are the same as presented in Fig. 4 in order to have uniformity. It is clear from Fig. 5 that the $\Delta \mathrm{T}$ (temperature differences between land and sea) is positive during daytime indicating that land surface is warmer than adjoining sea and $\Delta \mathrm{T}<0$ during nocturnal period. The onset of sea breeze, can be interpreted by the shift in $\Delta \mathrm{T}$ from negative to positive, is observed to be around 09:00 IST for onshore cases and around 10:00 IST for offshore and along-shore cases. The peak values of $\Delta \mathrm{T}$ during offshore, along-shore and onshore are about 5.18, 5.0, and $4.5{ }^{\circ} \mathrm{C}$ respectively around 13:00 IST. Irrespective of the synoptic-scale wind flow the temperature differences remained almost stable between 11:00 IST and 14:00 IST before start to decrease. The constant differences is associated with the advection of cool air mass from the adjoined sea. The air temperature over land decreased below adjoined sea surface temperature after 18:00 IST, and $\Delta \mathrm{T}$ remained negative indicating the dominance of cooling until morning. From Fig. 5 it is observed that the thermal forcing of daytime breeze is larger for offshore and along-shore cases, and minimum for onshore events. Though results are expected, it is noteworthy to mention the presence of stronger thermal forcing during daytime than the night-time over this coastal region. Due to the daytime thermal contrast between the land (warm) and sea (cool) sea breeze flows inland across the coastal region and reverse (land breeze) occurs during night-time. 
212 In addition to the thermal contrast of land-sea, prevailing synoptic wind flow also play a major role in 213 modulating the shape of the sea breeze, onset/cessation time of sea breeze and intensity of sea breeze (Prakash et

214 al. 1992; Finkele et al. 1995; Helmis et al. 1995). To investigate this, in this section, of the 58 cases of frontal

215 passages observed in the winter 2011-12, we present three distinct synoptic-scale wind flow cases such as offshore 216 wind (20 December 2011), alongshore wind (04 February 2012) and onshore wind (10 January 2012) observed 217 over the experimental site.

\section{3.3.1. 20 December 2011 (Offshore event)}

219 Figure 6 presents a typical example of offshore flow observed on 20 December 2011. It shows the diurnal 220 variations of the height-time cross-section of 10 minutes averaged signal-noise-ratio (SNR), zonal, meridional, 221 vertical wind, SBC and wind speed. During this day, weak synoptic winds ( $850 \mathrm{hPa})$ offshore northwesterlies prevail over the study region (Fig. S.2). Daytime evolution of the CABL due to increase in thermals caused by solar heating of the surface is discernible after 08:00 IST, which is characterized by an enhanced backscatter is indicated by an increase in SNR at higher altitudes $(80-220 \mathrm{~m})$ compared to their night-time values (Fig. 6a). Highest altitude up to which the SNR increases with time during the daytime is $\sim 220 \mathrm{~m}$, above which the diurnal variation of SNR is insignificant. This indicates that the altitude up to which the influence of thermal plumes generated near the surface is felt is $<200 \mathrm{~m}$. The time-height variation of SNR is largest and rapid between 08:0011:30 IST. The above variations show that the CABL height increases from $<80 \mathrm{~m}$ at 08:00 IST to $\sim 220 \mathrm{~m}$ at 10:30 IST during this day. Afterwards, the fluctuations in SNR is noticed until 11:30 IST. The sodar return power shows a significant reduction in the height coverage from $220 \mathrm{~m}$ at 10:30 IST to $140 \mathrm{~m}$ at 11:00 IST, followed by an increase in the SNR till 11:30 IST, and a continuous, horizontally stratified structure is visible till 13:00 IST. The reduction in the SNR is due to inhibition of large-scale motions with the onset of the sea breeze and the 233 formation of the thermal internal boundary layer (TIBL) (Prakash et al. 1992; Kunhikrishnan et al. 1993; Prabha et al. 2002). On this day, though the sea breeze first arrived around 10:30 IST, it is not well established until 11:30 IST (see Fig. S.1: the offshore case for clarity). The delayed onset of the sea breeze is evident from a noticeable shift from negative to positive in the $\Delta \mathrm{T}$ (temperature differences between land and sea) around 10:00 IST (Fig. 7). The sodar observations of SNR did not decrease drastically after the onset of sea breeze and remains almost steady till 13:00 IST, which is followed by a consistent decrease in SNR with time, especially up to 16:00 IST, indicating the systematic decrease in CABL height associated with the reduction in the intensity of thermals. The time-height variations of SNR attain the typical nocturnal atmospheric boundary layer structure by $\sim 18: 00$ IST. 

gradual reduction in the magnitudes of meridional winds (Fig. 6c) is observed at all altitudes during this period.

243 This feature is seen by a marked shift in the SBC from negative (land breeze) to positive (sea breeze) at all altitudes 244 indicating the onset of sea breeze (Fig. 6e). The onset of sea breeze on this day is almost $1 \mathrm{hr} 30$ minutes delay 245 compared to the most probable time of onset i.e 10:00 IST during the winter over the experimental site. The 246 delay in the onset of the sea breeze is characterized by the prevailing strong northwesterly winds observed on this 247 day. As described by Miller et al. (2003), the strong southward components of the background wind over the east coast in northern hemisphere favour the delay in onset of sea breeze (characterized by veering of winds or backdoor sea breeze). The intensity of SBC gradually increases and reaches the maximum value of about $2.5 \mathrm{~ms}^{-}$ ${ }^{1}$ at height around 120-140 m during the late afternoon (between 13:00 - 14:00 IST). The present observations corroborate the 2D-model study by Arritt (1993), indicated that for weak offshore synoptic conditions, sea breeze intensifies just after the maximum solar insolation near the coasts. Associated with the onset of sea breeze, vertical velocities undergo significant changes from downdrafts to updrafts before and after the onset (Fig. 6d). At 11:30 IST a downdraft of about $0.15 \mathrm{~ms}^{-1}$ is observed up to $80 \mathrm{~m}$, followed by an updraft reaching about $0.3 \mathrm{~ms}^{-1}$, in general, to heights of about $200 \mathrm{~m}$, indicating the convergence of sea breeze front at higher heights (Helmis et al. 1987;1995; Prakash et al. 1992; Chiba, 1993; Stephan et al. 1999). The low values of vertical velocities observed in the present results are due to the averaging time of vertical velocities is about 10 minutes. The noontime maximum wind speed is found to be around $4 \mathrm{~ms}^{-1}$ around the 120-140 m height region (Fig. 6f).

\subsubsection{February 2012 (Along-shore event)}

On the 04 February 2012 (Sunrise at 06:29 IST and sunset at 05:53 IST) early morning low northeasterly synoptic wind conditions prevail over the experimental site (Fig. S.3). The Doppler sodar averaged winds also shows northeasterly winds at all observed heights before and after the sunrise (Figs. 8b,c). As the day progress, the variability in wind speed and direction is observed until 10:30 IST. Later on, the veering of wind (rotates in the clockwise direction) from nocturnal northeasterly (land breeze) to southeasterlies (sea breeze) is seen until later was well established. It is evident from the SBC (Fig. 8e) that the sea breeze onset occurs at 10:30 IST and the magnitudes of SBC gradually increases and reaches maximum values of around $3 \mathrm{~ms}^{-1}$ between 80 and $140 \mathrm{~m}$ during 12:00-13:00 IST. The average wind speeds (Fig. 8f) between 120 and $140 \mathrm{~m}$ increases from $<2 \mathrm{~ms}^{-1}$ at 10:30 IST (time of onset of the sea breeze) to $5 \mathrm{~ms}^{-1}$ at 12:50 IST, while the direction of the wind remains southeasterlies during 10:30 to 17:00 IST. The results are in consistent with that of Atkins and Wakimoto (1997) who showed that, an increase in the sea breeze in the afternoon during parallel flow conditions. 
The sodar vertical velocity profiles (Fig. 8d) changes from downdrafts to updrafts before and after the onset.

272 A surge in the updrafts around 10:30 IST is noticed due to the physical wedge of the cool (dense) marine air mass 273 interacting with the warm (lighter) land air mass. The magnitudes of the updrafts are about $0.3 \mathrm{~ms}^{-1}$, extends to a 274 height of about $140 \mathrm{~m}$. These updrafts are responsible for the depth of the sea breeze (Miller et al. 2003). 275 Additionally, sodar vertical velocities show updrafts and downdrafts during the sea breeze, which are due to surface friction and thermal instability caused by the movement of marine air across the land surface. The updraft (+ve) represents the buoyancy generated motion and downdraft (-ve) the compensated regions of negative vertical velocity. These regions are responsible for the transport of fluxes of momentum and energy from the surface. The signal-noise-ratio of sodar data (Fig. 8a), which is an indicative of the backscatter signal corresponding to the fluctuations of thermals, did not show any changes during the time of onset of sea breeze, instead, shows a systematic increase during the evolution of CABL to reach a maximum height of about $220 \mathrm{~m}$ at 11:30 IST. The forenoon (11:00 - 12:00 IST) peak values of CABL height over the coastal regions were reported over other regions as well (Zhang et al. 2012; Rajeev et al. 2016; Davis et al. 2021). The SNR in the altitude region below $\sim 180 \mathrm{~m}$ remains almost steady during $\sim 12: 00$ to $\sim 15: 00$ IST, which is followed by a consistent decrease in SNR with time, especially up to $\sim 17: 00$ IST at all altitudes above $\sim 100 \mathrm{~m}$. The enhancement of SNR in the lower heights during the sea breeze period may be due to the mechanical turbulence caused due to the formation of TIBL (Helmis et al. 1995).

\subsubsection{January 2012 (Onshore event)}

On the 10 January 2012 (Sunrise at 06:30 IST and sunset at 05:39 IST) weak easterly synoptic flow conditions prevail over the experimental site (Fig. S.4). The Doppler sodar averaged winds also show low WSW wind flow below $100 \mathrm{~m}$ before and after the sunrise (Figs. 9(b, c)). The. direction of the wind is westerly up to 07:20 IST, which is followed by a gradual change in direction of the wind in anticlockwise (from westerlies to southeasterlies) till 08:30 IST (see Fig. S.1: onshore wind for clarity). The magnitude of zonal wind shifts from weak westerly to easterly at all altitudes around 08:00 IST (Fig. 9b), while meridional winds (Fig. 9c) increases from weak southerlies $\left(<1 \mathrm{~ms}^{-1}\right)$ to strong southerlies $\left(>2 \mathrm{~ms}^{-1}\right)$ and attain a maximum value of about $4 \mathrm{~ms}^{-1}$ during 12:00-13:00 IST at all altitudes. It is evident from the SBC (Fig. 9d) that the onset of sea breeze occurs at 08:10

297 IST and the magnitudes of SBC increases during noontime and remains steady till 15:40 IST. Fig. 7 further confirms that there exists an early onset of sea breeze on this day. After the onset of sea breeze, wind speed (Fig. 9f) shows a gradual increase from till noontime, while the direction of the wind remains more or less remain south easterlies. The intensity of wind speed and SBC observed in this case, are not so strong compared to onshore and 

breeze observed on the onshore case is early i.e. around 08:10 IST which is almost $2 \mathrm{hrs}$ before the most probable

303 time of onset during winter. The early onset is due to the presence of prevailing southwesterly which enable the early onset of corkscrew sea breeze (Miller et al. 2003). As pointed out by Miller et al. (2003), the northward component in the northern hemisphere favours the early onset of sea breeze (characterized by anticlockwise rotation of winds or corkscrew sea breeze).

Similar to the other two cases, with the passage of sea breeze, the vertical velocities (Fig. 9d) shift from downdrafts to updrafts in all observed heights. However, the magnitudes of vertical velocities (both up-, and downdrafts) are less during the passage of sea breeze compared to the other two cases. This may be due to the combined effect of weak background wind and sea breeze circulation cell exist on a larger scale (Helmis et al. 1995). The vertical velocities exhibit a systematic up- and downdrafts during the sea breeze period during the onshore case and the range of periodicities is consistent with the earlier studies over the India coastal sites made with sodar measurements (Prabha et al. 2002).

The Doppler sodar SNR (Fig. 9a) which describes the turbulent structure of the low-level boundary layer shows an enhancement below $60-80 \mathrm{~m}$. The enhancement in the backscatter power is due to the mechanical turbulence during night-time and both convective and mechanical turbulence during the daytime. As the day progress, CABL increases and associated sodar backscatter deepens and the strength of SNR increase within this layer and reaches a maximum height of $160 \mathrm{~m}$ around 10:00 IST and remains steady around this height till 15:00 IST, thereafter decreases till 17:00 IST. On this day, SNR did not show significant variation in both height coverage and intensity at the time of onset as compared to the alongshore event of 04 February 2012.

\subsection{Characteristics of sea breeze front}

Figure 10 highlights the impact on the vertical structure of the sea breeze as observed by Doppler sodar under the influence of offshore (top panel), along-shore (middle panel) and onshore (bottom panel). The SBC, vertical velocity and wind speed presented in the figures obtained after carrying out an equivalent day analysis of the above-mentioned wind regimes collected during the study period. From the Figures, it is apparent that the synoptic flow relative to the coast plays a significant role in the modulating the vertical structure and evolution of the sea breeze over the experimental site.

The top panel in Fig. 10 corresponds to the equivalent day analysis of 37 offshore flow cases. The composite analysis of offshore cases shows that the most probable time of onset of sea breeze around 11:00 IST (Fig. 10a). 
331 at all observational altitudes $(40-180 \mathrm{~m})$. After the onset, SBC increases gradually during the day reaches a 332 maximum during the noontime and remain steady till 15:00 IST indicating the passage of the sea breeze front.

333 The averaged vertical velocities (Fig. 10b) show a surge in the updrafts associated with the onset of sea breeze

334 and reach a maximum height up to $180-200 \mathrm{~m}$, indicating the convergence of the sea breeze front to reach higher

335 heights (Helmis et al. 1995). A systematic up- and downdrafts associated with the passage of the sea breeze is

336 observed. The average of vertical velocity brought out the consistent features of sea breeze structure. Most of the

337 features observed during the individual cases are reproduced indicating the predominant and consistent vertical

338 variations observed during the individual offshore cases. Noteworthy to mention that on almost all individual days

339 there is an existence of downdrafts and updrafts before and after the onset of the sea breeze irrespective of synoptic

340 flow conditions (e.g., Chiba 1993; Helmis et al. 1995). However, vertical velocity varies with the synoptic wind

341 conditions. Stronger up-surge is noticed after the onset of sea breeze for offshore cases compared to the other two

342 cases. The results fit better to the earlier studies (Estoque 1962; Helmis et al. 1987). A noticeable feature seen in

343 Fig. 10c is that wind speed is high $\left(\sim 4 \mathrm{~ms}^{-1}\right)$ before the onset of sea breeze, slows down to $3 \mathrm{~ms}^{-1}$ around the onset

344 time. Afterwards continue to increase as the day progress, reaches higher wind speeds associated with the sea

345 breeze during late noontime, a typical condition of sea breeze characteristics (Pearson 1973; Pielke 1974; Simpson

346 1994). Turbulence plays an important role in regulating the speed of sea breeze during the daytime (Ogawa et al.

347 2003), the slow increase in wind speed till early noontime can be ascribed to the presence of turbulence, before

348 accelerating again during late noontime as turbulence diminishes. The cessation of the sea breeze is well

349 identifiable by the reversal in the sign of SBC around 17:00 IST. Strikingly, the cessation occurs first in the lower

350 heights and then aloft, a similar feature observed in other cases also. After cessation, the wind speed decreases

351 below $1.5 \mathrm{~ms}^{-1}$ and vertical velocities shows downdrafts.

352 The middle panel in Fig. 10 shows the Doppler sodar observations of 13 alongshore wind flow. On an 353 average the onset of the sea breeze for along shore events occurs around 10:10 IST seen by a discernable shift in the SBC from negative to positive (Fig. 10d). After the onset, SBC changes significantly both in magnitudes and in heights as the day progress. The averaged vertical velocities (Fig. 10e) show similar features as offshore cases during the sea breeze time. Interestingly, a systematic up- and downdrafts in the vertical velocities with dominant updrafts are noticed and the vertical extent of the sea breeze is below $180 \mathrm{~m}$. Wind speed is very weak before the onset of sea breeze, strengthens during the daytime, associated with sea breeze attains maximum values of about $2.5 \mathrm{~ms}^{-1}$ during noontime in between 100 and $180 \mathrm{~m}$ height (Fig. 10f). Wind speed is stronger than the other two cases. The wind speed attains minimum during the cessation of sea breeze around 16:30 IST. 

individual cases, the mean features also reveal an early onset of sea breeze between 08:30 and 09:00 IST noticed

363 by a shift in the SBC from negative to positive (Fig. 10g). When compared to the other two cases, the onset of the sea breeze is shallow during the onshore case. The intensity of SBC observed to be stronger during noontime compared to other cases indicating the winds aligned perpendicular to the coast i.e. southeasterly. The intensity of SBC is strong $\left(>2 \mathrm{~ms}^{-1}\right)$ during onshore and alongshore during the afternoon (12:00-13:00 IST). The strengthening of sea breeze occurs when the sea breeze flow and ambient flow are in the same direction. Whereas, the intensity of SBC is relatively less $\left(<3 \mathrm{~ms}^{-1}\right)$ in offshore case. These results are in agreement with the observations by Atkins and Wakimoto (1987) simulation studies by Gilliam et al. (2004). The late afternoon strengthening of the sea breeze is in agreement with the numerical study of Arritt (1993) as well as observational studies (Atkins and Wakimoto 1997; Gilliam et al. 2004; Molina and Chen 2009). The averaged vertical velocities (Fig. 10h) show similar feature as in the other two cases but the vertical extent of the sea breeze is restricted to $140 \mathrm{~m}$. These observations are in accordance with the simulation results by Gilliam et al. (2004) who reported that the depth of the sea breeze fronts, measured by the level of upward motions of vertical velocity is different between offshore, parallel and onshore flow conditions. The duration of the sea breeze is longer in onshore flow than the other two cases (Sivaramakrishnan and Prakash Rao 1989; Molina and Chen 2009). Interestingly, Fig. 8 i shows that very low wind speed is observed before the onset of sea breeze strengthens during the daytime attains maximum values of about $3 \mathrm{~ms}^{-1}$ in between $60-140 \mathrm{~m}$ during noontime. The intensification in the SBC and wind speed is found to be at $120 \mathrm{~m}$ height level and not observed near the lower altitudes, probably because of intense mixing of turbulence in the surface layer.

\section{Conclusions}

The influence of prevailing background winds on the sea breeze over the coastal station Visakhapatnam $\left(17.7^{\circ} \mathrm{N}, 83.3^{\circ} \mathrm{E}\right)$ has been investigated using Doppler sodar observations collected during the winter months (December 2011-February 2012). The background wind was obtained from daily ERA-reanalysis at $850 \mathrm{hPa}$. The prevailing wind regimes were categorized into 3 groups offshore, alongshore and onshore. Total of 58 days of well-defined sea breeze cases are considered in this study. From the selected sea breeze cases of Doppler sodar observations, we focused on the sea breeze features like onset time of sea breeze, its duration, the strength of the sea breeze and its depth under the influence of background wind conditions. Following are the major findings: distribution between ERA at $850 \mathrm{hPa}$ and sodar at $60 \mathrm{~m}$. These results demonstrate the significance of the sea breeze in the local circulation. 
2) Strength of sea breeze are modulated by the large-scale wind flow and show substantial variation between offshore, along-shore and onshore: The strength of sea breeze component (SBC) is strong $\left(>2 \mathrm{~ms}^{-1}\right)$ during onshore and alongshore during the afternoon (12:00-14:00 IST). Whereas, the strength of SBC is relatively less $\left(<3 \mathrm{~ms}^{-1}\right)$ in offshore case. During onshore flow cases, the strengthening of sea breeze occurs when the sea breeze flow and ambient flow are in the same direction. Strengthening of the sea breeze in the late afternoon are in agreement with the numerical study of Arritt (1993) as well as observational studies (Atkins and Wakimoto 1997; Gilliam et al. 2004; Molina and Chen 2009).

3) The role of thermal forcing on the breeze circulation was investigated: Results show that temperature difference between land and sea $(\Delta \mathrm{T})$ is larger for offshore and along-shore when compared to that of onshore flow. Also, it is observed that irrespective of the synoptic-scale wind flow, $\Delta \mathrm{T}$ remain almost constant between 11:00 IST and 14:00 IST before start to decrease. The constant differences is associated with the advection of cool air mass from the adjoined sea.

4) Out of total 58 days of well-defined sea breeze cases observed during winter season, occurrence of offshore flow (37) are more compared to along-shore (13) and less frequent onshore flow cases (8).

5) The time of onset of sea breeze can occur as early as 08:00 IST during onshore winds. While for offshore winds, the onset of sea breeze has been observed as late as 12:30 IST. Duration of the sea breeze is less for the offshore case than the onshore case.

6) The strength of wind speed at the time of onset is more in offshore flow $\left(\sim 4 \mathrm{~ms}^{-1}\right)$ and weak for onshore flow $\left(<2 \mathrm{~ms}^{-1}\right)$ and alongshore $\left(<3 \mathrm{~ms}^{-1}\right)$. Furthermore, the depth of the sea breeze is higher $(\sim 220 \mathrm{~m})$ for the offshore than onshore $(\sim 160 \mathrm{~m})$.

413 velocity. The vertical velocities are restricted to lower heights for the onshore flow cases comparted to along414 shore followed by onshore cases.

415 8) Results show that intensification in the SBC and wind speed is found to be at $120 \mathrm{~m}$ height level and not 416 observed near the lower altitudes, probably because of intense mixing of turbulence in the surface layer.

417 The statistical analysis of sea breeze circulation presented in this work demonstrate the distinct behavior in 418 the structure and evolution of sea breeze (in terms of vertical extent, intensity) using high temporal and vertical 419 resolution of sodar observations under different synoptic-scale wind flow. In this study, the importance of the 420 effect of early and delay onset of sea breeze on the evolution of sea breeze structure are clearly brought out as such results are sparse over the coastal regions. Our observations and findings could aid i) the modelling 

interested in the quantification of vertical velocities under distinct wind flow conditions, iii) for better understanding on the vertical mixing of aerosols and trace gases which have profound importance over the industrialised coastal zones like Visakhapatnam where air pollution is a major concern. To improve the present results, further examination of the database such as inclusion of surface based meteorological data and thermodynamical profiles using balloon ascends are essential. This is especially required to further explanation of vertical extension of sea breeze (which is lacking in the present study). Such studies have not been carried out over this region and the aspects will be addressed in future.

430

\section{Acknowledgements}

432 The authors wish to thank the Indian Space Research Organization Bangalore, for the financial support is 433 provided by ISRO-GBP under NOBLE Project. The authors acknowledge the very useful suggestions by an 434 anonymous reviewer for their extensive comments and suggestions, which greatly led to improve the quality of 435 the manuscript. ERA-Interim reanalysis data were obtained from http://apps.ecmwf.int/datasets/data/. Authors 436 declare that there is no conflict of interest in the results and data.

437 Funding Statement: "This work was supported by ISRO-GBP under NOBLE Project. Author Prof. K. Niranjan 438 has received research support from Company ISRO-GBP under NOBLE project."

439 Competing Interests: "The authors have no relevant financial or non-financial interests to disclose."

440 Authors' contribution: Dr. N.V.P. Kiran Kumar conceptualized and wrote the manuscript; Analysis and 441 collection of the data was done by Dr. K Jagadeesh. Prof. K Niranjan supplied the data collected over 442 Visakhapatnam.

443 Data availability: The Doppler sodar data can be acquired from the Space Physics Laboratory by requesting to 444 Dr. Kiran Kumar, e-mail: kirankumar_nvp@vssc.gov.in.

\section{Compliance with ethical standards:}

446 Conflict of interest: The authors declare that they have no conflict of interest.

447 Code availability: Codes are available on request at kirankumar_nvp@vssc.gov.in

448 Consent to Participate: The authors declare consent to Participate.

449 Consent for Publication: The authors declare consent for publication. 
Anandan VK, Kumar MS, Rao IS (2008) First results of experimental tests of the newly developed NARL phasedarray Doppler Sodar. J Atmos Oceanic Technol 25: 1778-1784

Anurose TJ, Subrahamanyam DB, Sunilkumar SV (2016) Two years observations on the diurnal evolution of coastal atmospheric boundary layer features over Thiruvananthapuram $\left(8.5^{\circ} \mathrm{N}, 76.9^{\circ} \mathrm{E}\right)$. India Theor App Clim 131:77-90. https://doi.org/10.1007/s00704-016-1955-y

Arritt RW (1993) Numerical modeling of the offshore extent of sea breezes; Q J R Meteorol Soc 115: 547-570

Asimakopoulos DN, Deligiorgi D, Drakopoulos C, Helmis C, Kokkori K, Lalas D, Sikiotis D, Varotsos C (1992) An experimental study of night-time air-pollution transport over complex terrain in Athens. Atmos Environ 2611:59-71.

Atkins NT, Wakimoto RM, Weckwerth TM (1995) Observations of the sea-breeze front during CaPE, part II: Dual-doppler and aircraft analysis. Mon. Weather Rev 123:944-969

Atkins NT, Wakimoto RM (1997) Influence of the synoptic scale flow on sea breezes observed during CAPE. Mon Weather Rev 125: 2112-2130.

Augustin P et al. (2020) Impact of Sea Breeze Dynamics on Atmospheric Pollutants and Their Toxicity in Industrial and Urban Coastal Environments. Remot Sens 12, 648. https:// doi:10.3390/rs12040648

Bajamgnigni GAS, Steyn DG (2012) Sea breezes at Cotonou and their interaction with the West African Monsoon. Int J Climatol 33:2889-2899

Borne K, Chen D, Nunez M (1998) A method for finding sea breeze days under stable synoptic conditions and its application to the Swedish west coast. Int J Climatol 18:901-914

Chiba O (1993) The turbulent characteristics in the lowest part of the sea breeze front in the atmospheric surface layer. Boundary-Layer Meteorol 65:181-195

Chiba O (1997) Variability of the sea-breeze front from sodar measurements. Boundary-Layer Meteorol 82: 165174.

Crosman ET, Horel JD (2010) Sea and lake breezes: A review of numerical studies. Boundary-Layer Meteorol 137:1-29

Crosman ET, Horel JD (2016) Winter lake breezes near the Great Salt Lake. Boundary-Layer Meteorol 159:439464

Davis EV, Rajeev K, Mishra MK (2020) Effect of clouds on the diurnal evolution of the atmospheric boundarylayer height over a tropical coastal station. Boundary-Layer Meteorol 175:135-152. https://doi.org/10.1007/s10546-019-00497-6

Davis EV, Rajeev K, Namboodiri KVS (2021) The Convective-Atmospheric-Boundary-Layer Height and its dependence upon Meteorological Variables At a Tropical Coastal Station during Onshore and Offshore Flows. Boundary-Layer Meteorol. https://doi.org/10.1007/s10546-021-00665-7.

Dee DP, et al. (2011) The ERA-Interim reanalysis: configuration and performance of the data assimilation system. Q J R Meteorol Soc https://doi.org/10.1002/qj.828

Estoque MA (1962) The sea breeze as a function of the prevailing synoptic situation. J Atmos Sci 19: 244-250

Federico S, Pasqualoni L, De Leo L, Bellecci C (2010) A study of the breeze circulation during summer and fall 2008 in Calabria, Italy. Atmos Res 97: 1-13

Finkele K, Hacker JM, Kraus H, Byron-Scott RAD (1995) A complete sea-breeze circulation cell derived from aircraft observations, Boundary-Layer Meteorol 73:299-317

Finkelstein PL, Kaimal JC, Gaynor JE, Graves ME, Lockhart TJ (1986) Comparison of wind monitoring systems. Pad II: Doppley. Sodars. J Atmos Oceanic Technol 3:594-604

Furberg M, Steyn DG, Baldi M (2002) The climatology of sea breezes on Sardinia. Int J Climatol 22:917-932

Gera BS, Saxena N (1996) Sodar data-A useful input for dispersion modeling. Atmos Environ 30:3623-3631

Gilliam RC, Raman S, Niyogi DDS (2004) Observational and numerical study on the influence of large-scale flow direction and coastline shape on sea-breeze evolution. Boundary-Layer Meteorol 111:275-300

Grachev AA, Leo LS, Fernando HJ, Fairall CW, Creegan E, Blomquist BW, Christman AJ, Hocut CM (2018) Air-sea/land interaction in the coastal zone. Boundary-Layer Meteorol 167:181-210

Helmis CG, Asimakopoulos DN, Deligiorgi DG, Lalas DP (1987) Observations of sea-breeze fronts near the shoreline. Boundary-Layer Meteorol 38:395-410

Helmis CG, Papadopoulos KH, Kalogiros JA, Soilemes AT, Asimakopoulos DN (1995) Influence of background flow on evolution of Saronic Gulf sea breeze. Atmos Environ 29:3689-3701

Kalogiros JA, Helmis CG, Asimakopoulos DN, Papageorgas PG (1999) Estimation of ABL parameters using the vertical velocity measurements of an acoustic sounder. Boundary-Layer Meteorol 91:413-449

Kitada T (1987) Turbulence structure of sea breeze front and its implication in air pollution transportApplication of k-e turbulence model. Boundary-Layer Meteorol 41:217-239 
KiranKumar NVP, Jagadeesh K, Niranjan K, Rajeev K (2019) Seasonal variations of sea breeze and its effect on the spectral behaviour of surface layer winds in the coastal zone near Visakhapatnam, India. J Atmos SolarTerr Phys https://doi:10.1016/j.jastp.2019.01.013 on the response of aerosol characteristics to land- and sea-breeze circulations at a coastal station. BoundaryLayer Meteorol https:// doi.org/10.1023/A:1023073929115

Kunhikrishnan PK, Sen Gupta K, Radhika Ramachandran, Winston Jeeva Prakash J, Narayanan Nair K (1993) Study on Thermal Internal Boundary Layer Structure over Thumba, India, Ann. Geophysicae 11:52-60

Mastrantonio G, Viola AP, Argentini S, Fiocco G, Giannini L, Rossini L, Abbate G, Ocone R, Casonato M (1994) Observations of sea breeze events in Rome and the surrounding area by a network of Doppler sodars. BoundaryLayer Meteorol 71:67-80

Melas D, Ziomas I, Klemm O, Zerefos CS (1998) Anatomy of the sea-breeze circulation in Athens area under weak large-scale ambient winds. Atmos Environ 32:2223-2237

Menut L, Flamant C, Pelon J (1999). Evidence of interaction between synoptic and local scales in the surface layer over the Paris area. Boundary-Layer Meteorol 93:269-286

Miller STK, Keim B, Talbot R, Mao H (2003). Sea breeze: structure, forecasting, and impacts. Rev Geophys. https://doi.org/10.1029/2003RG000124

Molina CA, Chen D (2009) Climatological study of the influence of synoptic-scale flows on sea breeze evolution in the Bay of Alicante (Spain), Theor Appl Climatol 96: 249-260

Niranjan K, Rao BM, Saha A, Murthy KSR (2004) Aerosol spectral optical depth and size characteristics at a coastal industrial location in India - effect of synoptic and mesoscale weather. Annales Geophysicae, 22: $1851-1860$

Ogawa S, Sha W Iwasaki T (2003) A numerical study of the interaction of a sea-breeze front with convective cells in the daytime boundary layer. J of Meteorol. Soc. of Jpn 81:635-651

Pearson RA (1973) Properties of the sea breeze front as shown by a numerical model. J Atmos Sci 30:1050- 1060

Pielke RA (1974) A Three-Dimensional Numerical Model of the Sea Breezes Over South Florida Mon. Weather Rev. 102: 115-139.

Porson ANF, Steyn DG, Schayes G (2007) Formulation of an index for sea breezes in opposing winds. J Appl Meteorol Clim 46:1257-1263

Prabha TV, Venkatesan R, Mursch-Radlgruber E, Rengarajan G, Jayanthi N (2002) Thermal internal boundary layer characteristics at a tropical coastal site as observed by a mini-SODAR under varying synoptic conditions. J Earth Syst Sci 111:63-77

Prakash JWJ, Ramachandran R, Nair KN, Sen Gupta K, Kunhikrishnan PK (1992) On the structure of sea-breeze fronts observed near the coastline of Thumba, India. Boundary-Layer Meteorol 59:111-124

Puygrenier V, Lohou F, Campistron B, Saïd F, Pigeon G, Bénech B, Serça D (2005) Investigation on the fine structure of sea-breeze during ESCOMPTE experiment. Atmos Res 74:329-353

Rajeev K,MishraMK, Sunilkumar SV, Sijikumar S (2016) Dual polarization micropulse lidar observations of the diurnal evolution of atmospheric boundary layer over a tropical coastal station. In: Proc. SPIE, Lidar remote sensing for environmental monitoring XV 98790. https://doi.org/10.1117/12.2228049

Rao P, Fuelberg HE (2000) An investigation of convection behind the Cape Canaveral sea-breeze front. Mon Weather Rev 128: 3437-3458

Rao Purnachandra, M, Raghyu Kumar A, Sree Rama Murthy J, Rao Poornachandra C (1981) Sea-Breeze Detection with Acoustic Radar. Ind. J. Rad. Space Phys., 10: 6-191

Simpson JE (1994) Sea Breeze and Local Wind, 234 pp., Cambridge Univ. Press, New York.

Simpson JE, Mansfield DS, Milford J.R (1977) Inland penetration of sea breeze fronts. Q J R Meteorol Soc 103:47-76

Singal SP, Aggarwal SK, Pahwa DR, Gera BS (1986) Acoustic sounding: A tool for monitor air pollution hazards: Indian J Env Health, 28:48-53

Sivaramakrishnan TR, Rao Prakash SP (1989) Sea Breeze Features over Sriharikota. Meteorol Mag 118: 64-67

Stephan K, Kraus H, Ewenz CM, Hacker JM (1999) Sea-breeze front variations in space and time. Meteorol Atmos Phys70:81-95

Steyn DG, Kallos G (1992) A study of the dynamics of hodograph rotation in the sea breezes of Attica, Greece. Boundary-Layer Meteorol 58:215-228

Stull RB (1988) An introduction to boundary layer meteorology. Kluwer Academic Publishers, Dordrecht/Boston/London

Zhang N, Chen Y, Zhao W (2012) Lidar and microwave radiometer observations of planetary boundary layer structure under light wind weather. J Appl Remote Sens 6:63513-63518. https://doi.org/10.1117/1.JRS.6.063513

Zhong S, Takle ES (1992) An observational study of sea-and land-breeze circulation in an area of complex coastal heating. J Appl Meteorol 31:1426-1438 
Table

Figure 1: Schematic diagram illustrating the wind direction for the three flow regimes defined in this study: offshore, alongshore and onshore. The dashed red line shows the sea breeze component (SBC) perpendicular to the coastline $\left(45^{\circ}-225^{\circ}\right)$

Figure 2: Spatial variation of seasonal mean wind at the $850 \mathrm{hPa}$ level during December 2011-February 2012 obtained from ERA-Interim reanalysis. The colour scale indicates wind speed and arrows indicate wind direction. Red colour ' $\star$ ' shows the location of the experimental site

Figure 3: Wind roses from ERA-850 hPa and sodar observations at $60 \mathrm{~m}$ during December 2011-February 2012

Figure 4: Time of onset of sea breeze and b) histogram of onset of sea breeze under the influence of offshore, along-shore and onshore flow during December 2011 to February 2012

Figure 5: The temperature difference between land and sea surface temperature (obtained from ERA Interim Reanalysis) near to the Visakhapatnam for offshore flow, along-shore and onshore cases observed during winter 2011-12

Figure 6: Time-height cross-sections of (a) signal-noise-ratio, (b) zonal wind, (c) meridional wind, (d) vertical wind, (d) sea breeze component and (e) wind speed observed by Doppler sodar over Visakhapatnam on 20 December 2011 (offshore flow). The vertical arrow indicates the onset of the sea breeze

Figure 7: The temperature difference between land and sea surface temperature (obtained from ERA Interim Reanalysis) near to the Visakhapatnam on 20-December-2011 (offshore), 04-February-2012 (alongshore) and 10-Janaury-2012 (onshore).

Figure 8: Same as Fig. 6, but for the along-shore event observed on 04 February 2012

Figure 9: Same as Fig. 6, but for the onshore flow observed on 10 January 2012

Figure 10: Time-height cross-sections of sea breeze component (a,d,g); vertical velocity (b,e,h) and wind speed $(c, f, i)$ observed by Doppler sodar observations under the influence of offshore (top panel), alongshore (middle panel) and onshore (bottom panel) during winter 2011-12

Table 1 Specifications of the Doppler sodar 

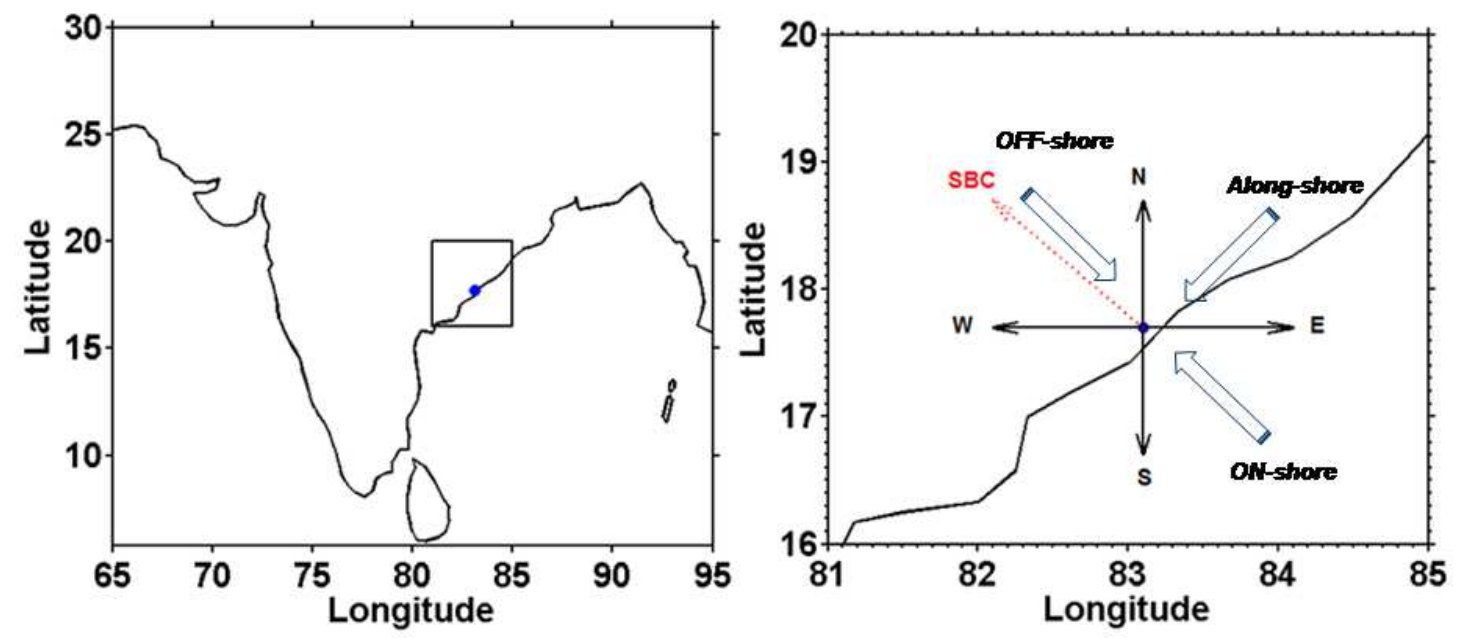

Fig.1 Schematic diagram illustrating the wind direction for the three flow regimes defined in this study: offshore, alongshore and onshore. The dashed red line shows the sea breeze component (SBC) perpendicular to the coastline $\left(45^{\circ}-225^{\circ}\right)$

602

603

604

605

606

607

608

609 


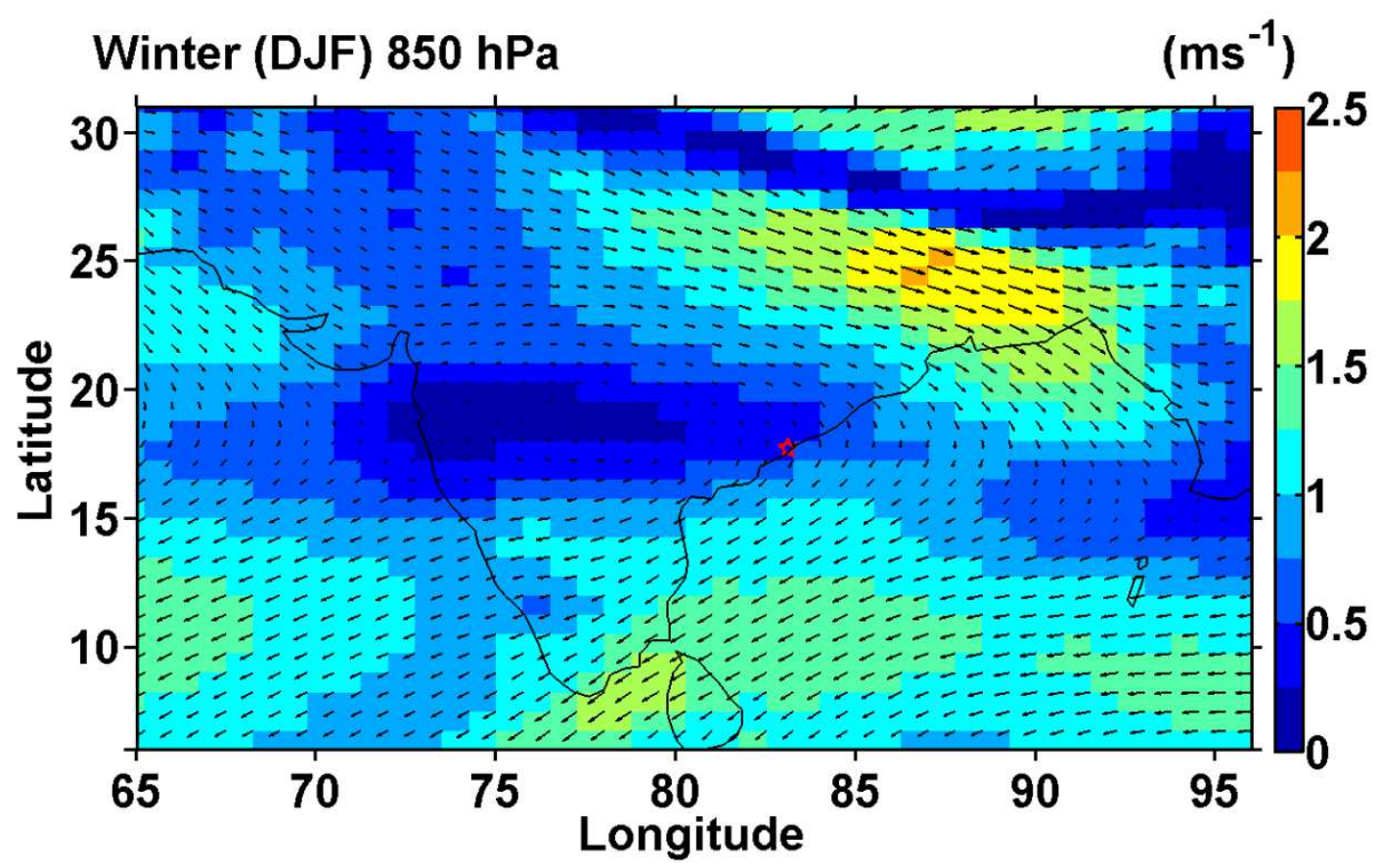

Fig. 2 Spatial variation of seasonal mean wind at the $850 \mathrm{hPa}$ level during December 2011-February 2012 obtained from ERA-Interim reanalysis. The colour scale indicates wind speed and arrows indicate wind direction. Red colour ' $\star$ ' shows the location of the experimental site 


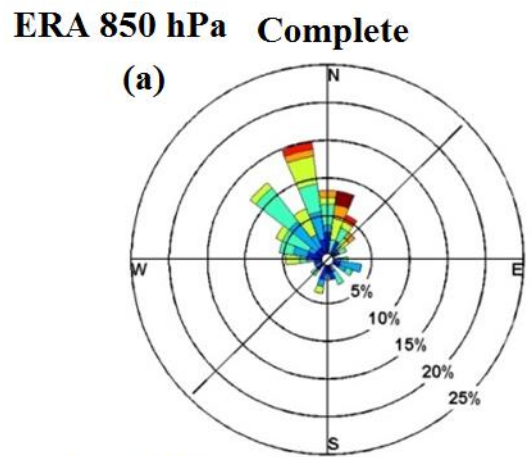

sodar at $60 \mathrm{~m}$

(d)

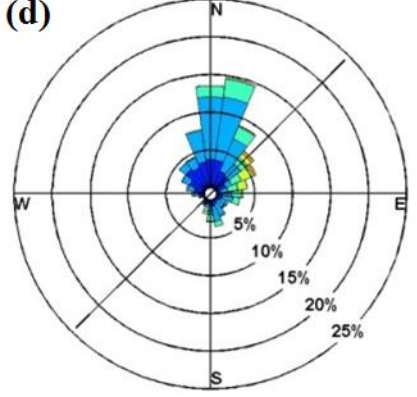

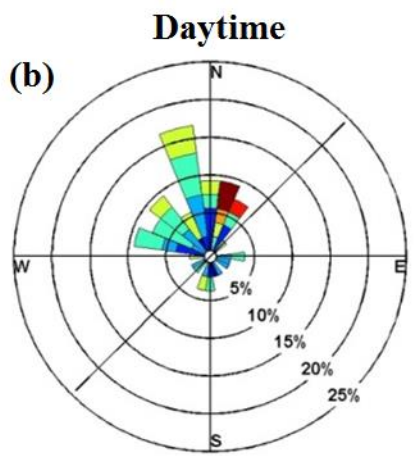

(e)

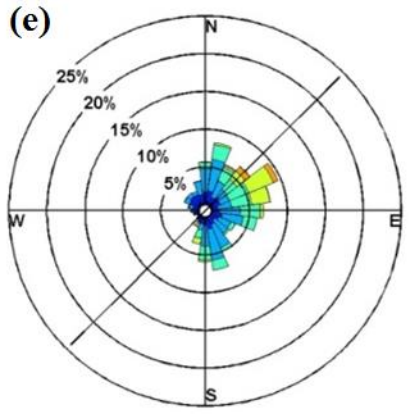

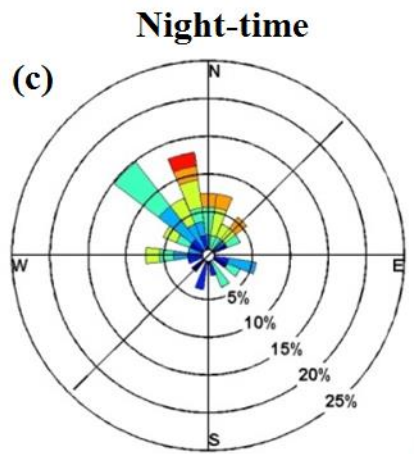

$\mathrm{ms}^{-1}$

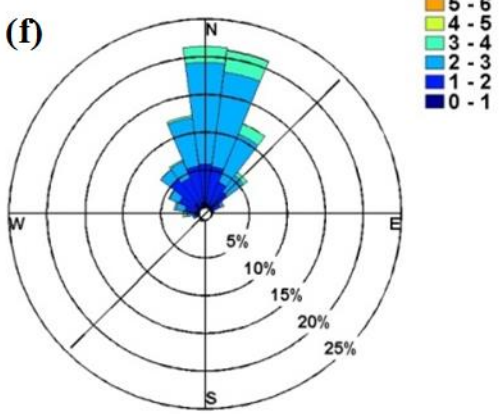

621

Fig. 3 Wind roses from ERA-850 hPa and sodar observations at $60 \mathrm{~m}$ during December 2011-February 2012

622

623

624

625

626

627

628

629

630 

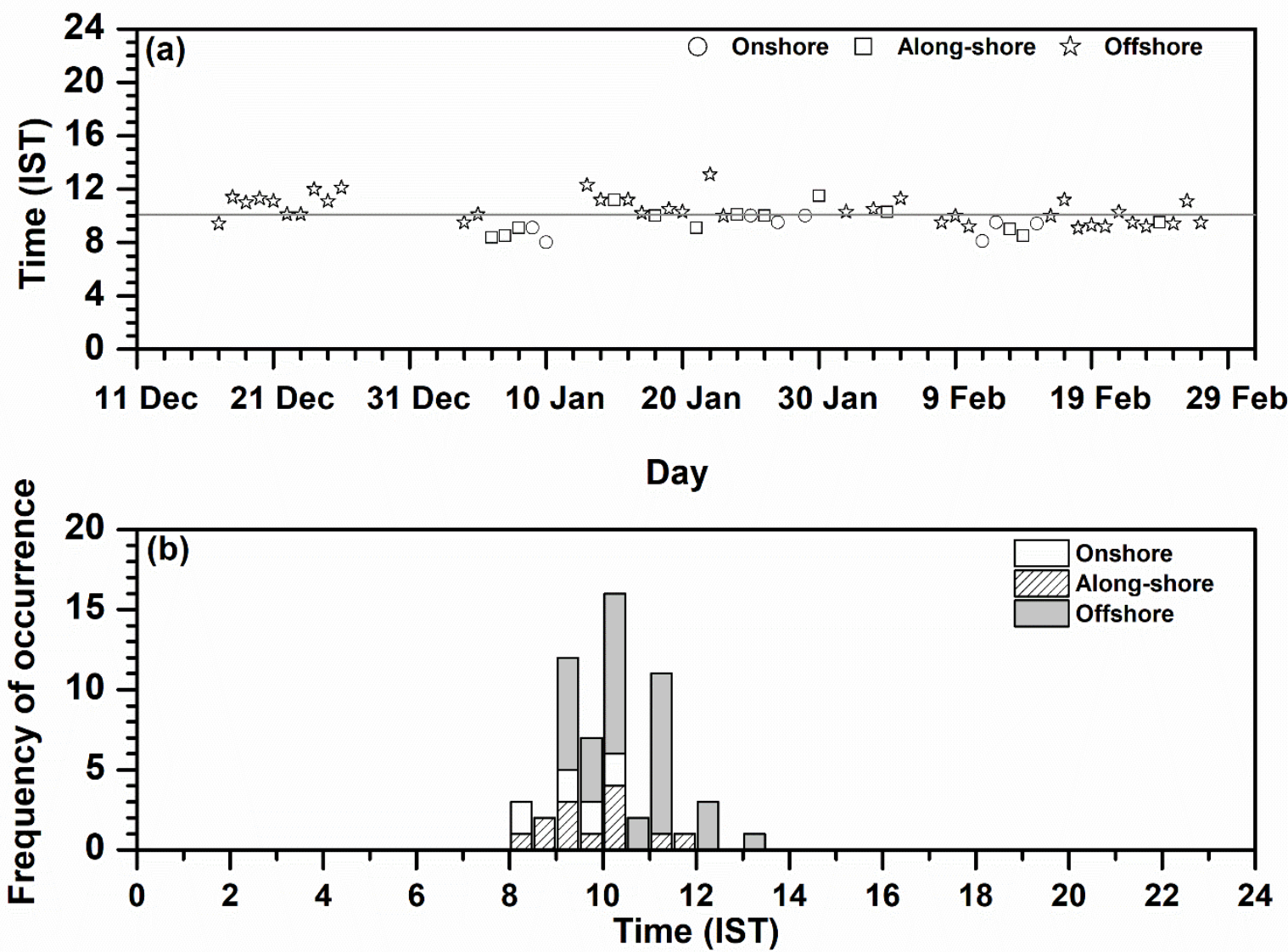

Fig. 4 a) Time of onset of sea breeze and b) histogram of onset of sea breeze under the influence of offshore, alongshore and onshore flow during December 2011 to February 2012. 
641

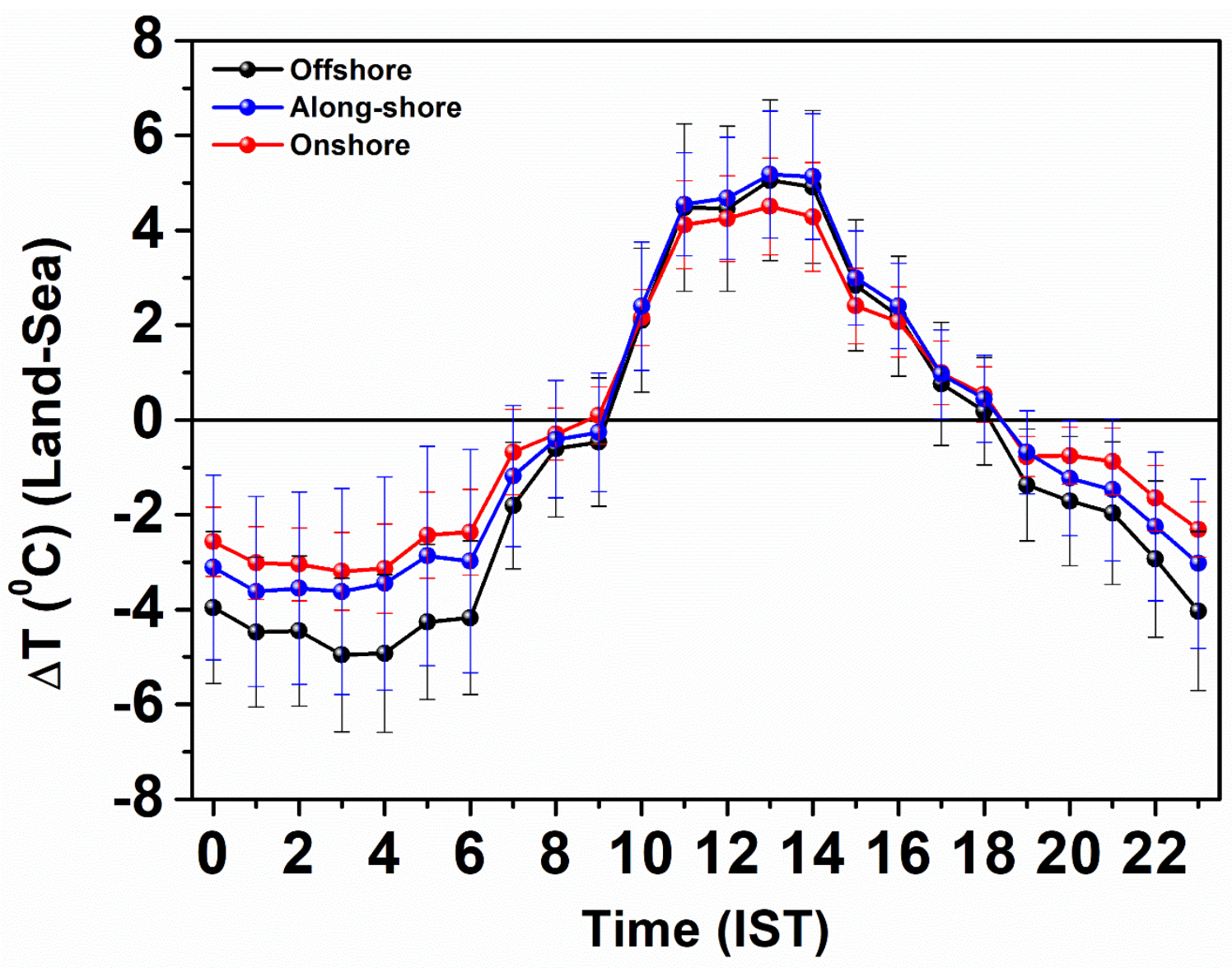

Fig. 5 The temperature difference between land and sea surface temperature (obtained from ERA Interim Reanalysis) near to the Visakhapatnam for offshore flow, along-shore and onshore cases observed during winter 2011-12 

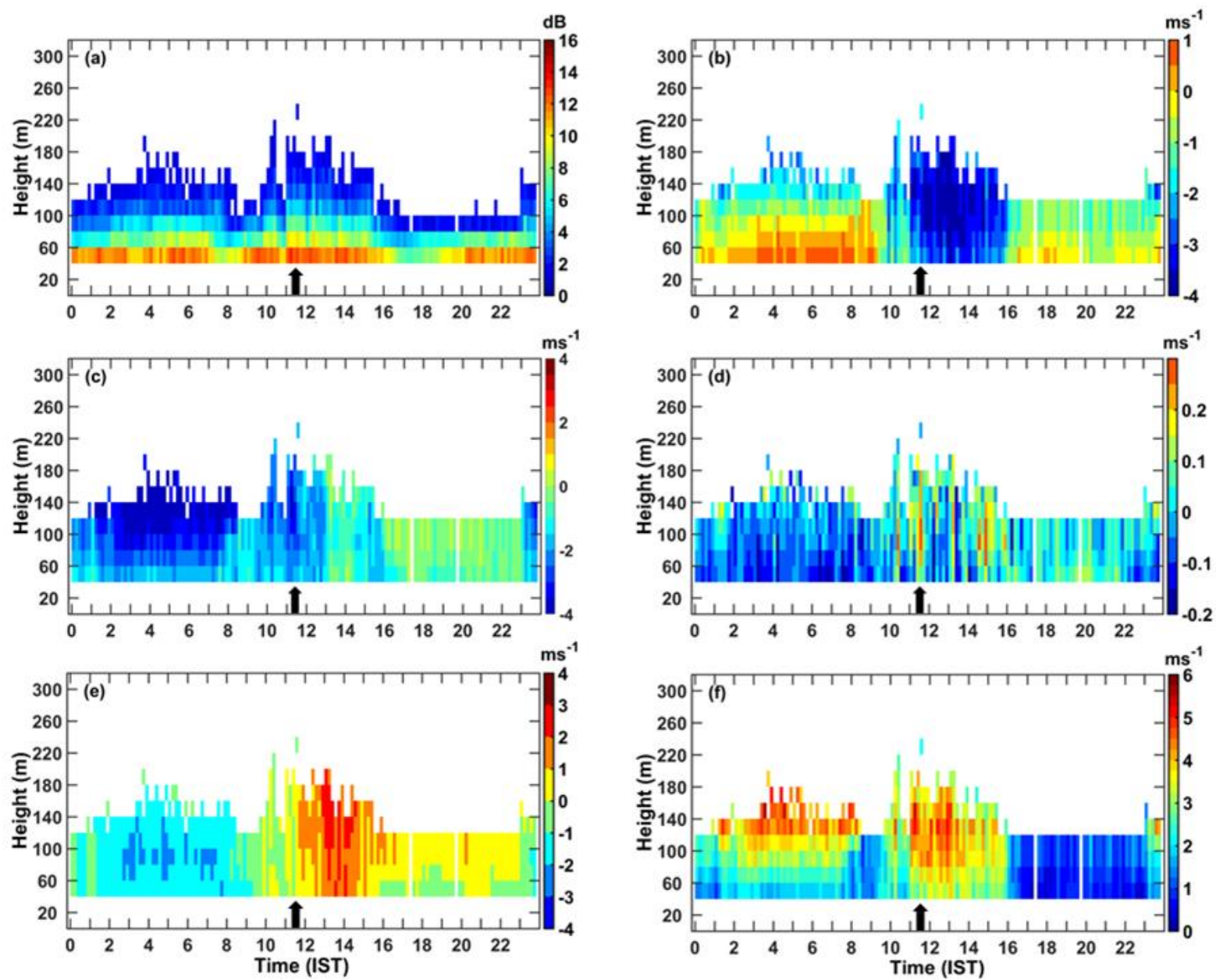

Fig. 6 Time-height cross-sections of (a) signal-noise-ratio, (b) zonal wind, (c) meridional wind, (d) vertical wind, (d) sea breeze component and (e) wind speed observed by Doppler sodar over Visakhapatnam on 20 December 2011 (offshore flow). The vertical arrow indicates the onset of the sea breeze 


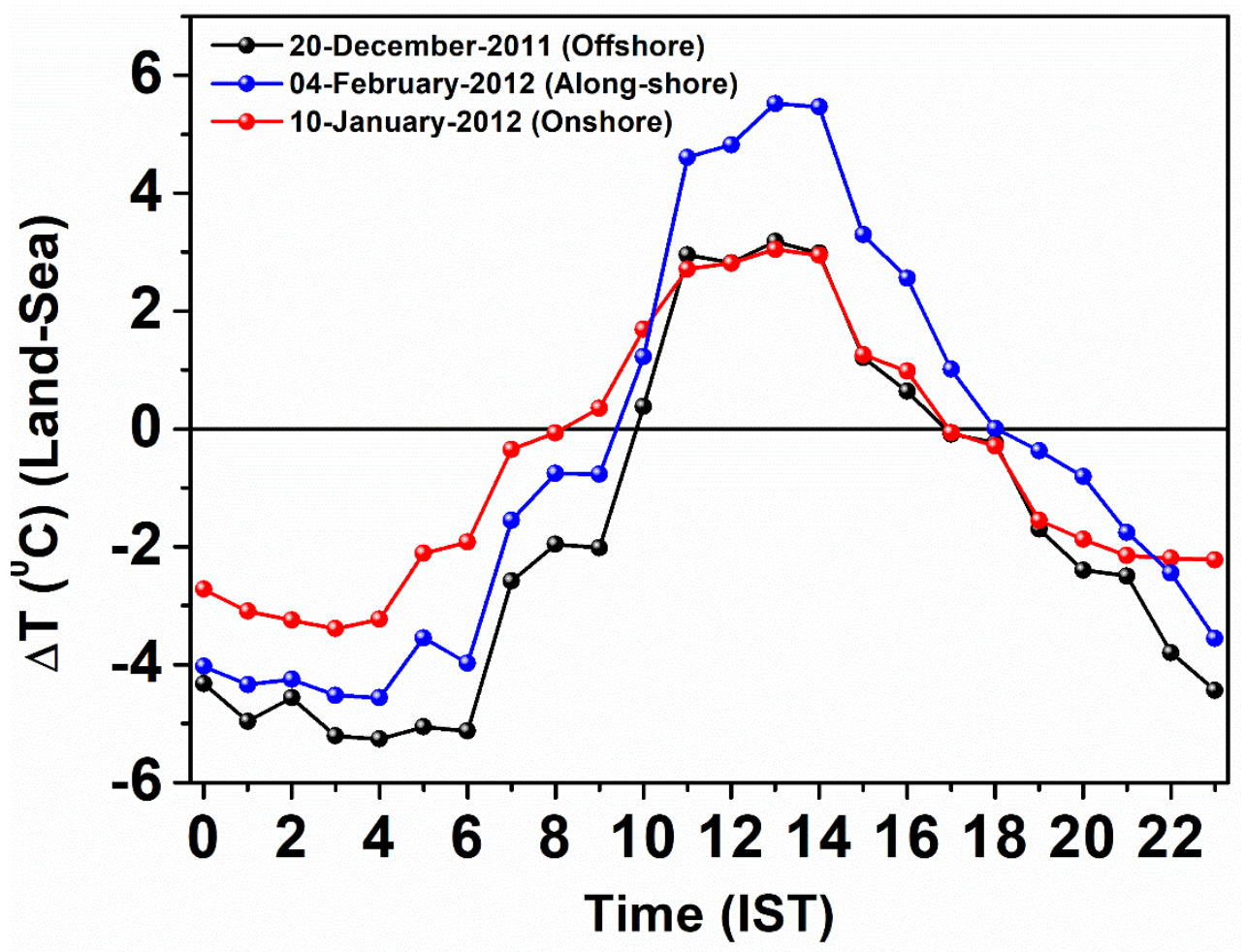

Fig. 7 The temperature difference between land and sea surface temperature (obtained from ERA Interim Reanalysis) near to the Visakhapatnam on 20-December-2011 (offshore), 04-February-2012 (along-shore) and 10-Janaury-2012 (onshore). 

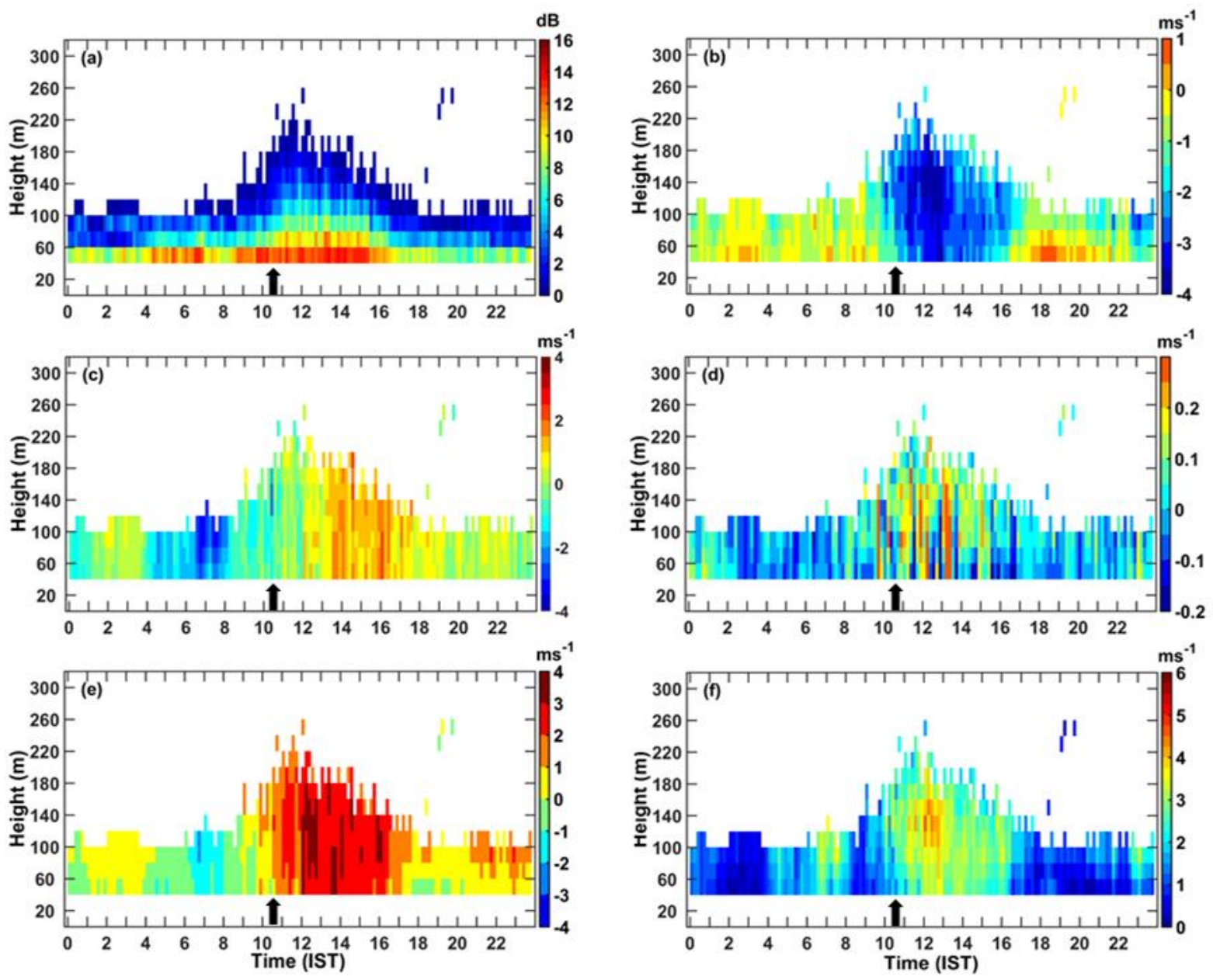

Fig. 8 Same as Fig. 6, but for the along-shore event observed on 04 February 2012

668

669

670

671

672

673

674 

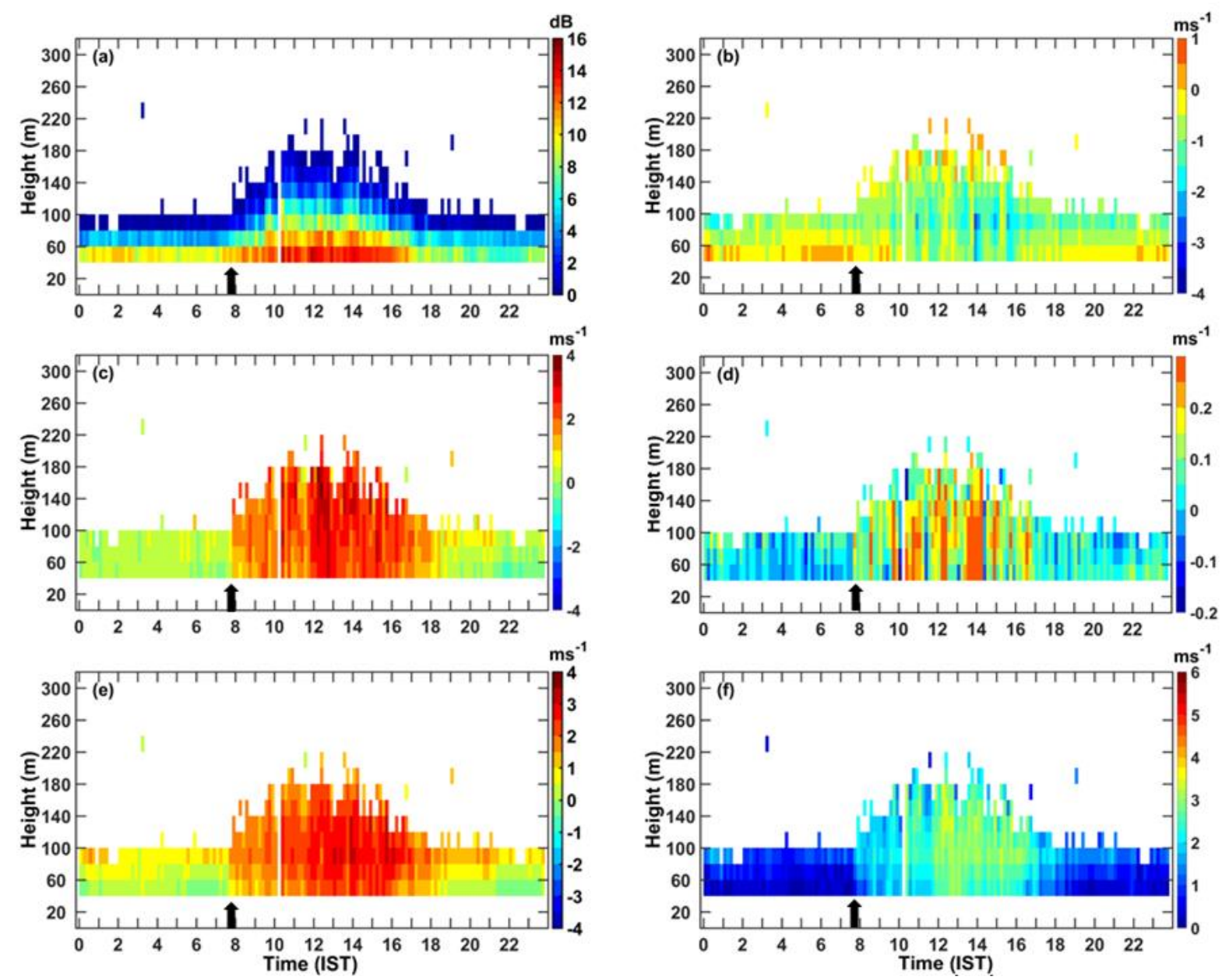

Fig. 9 Same as Fig. 6, but for the onshore flow observed on 10 January 2012 

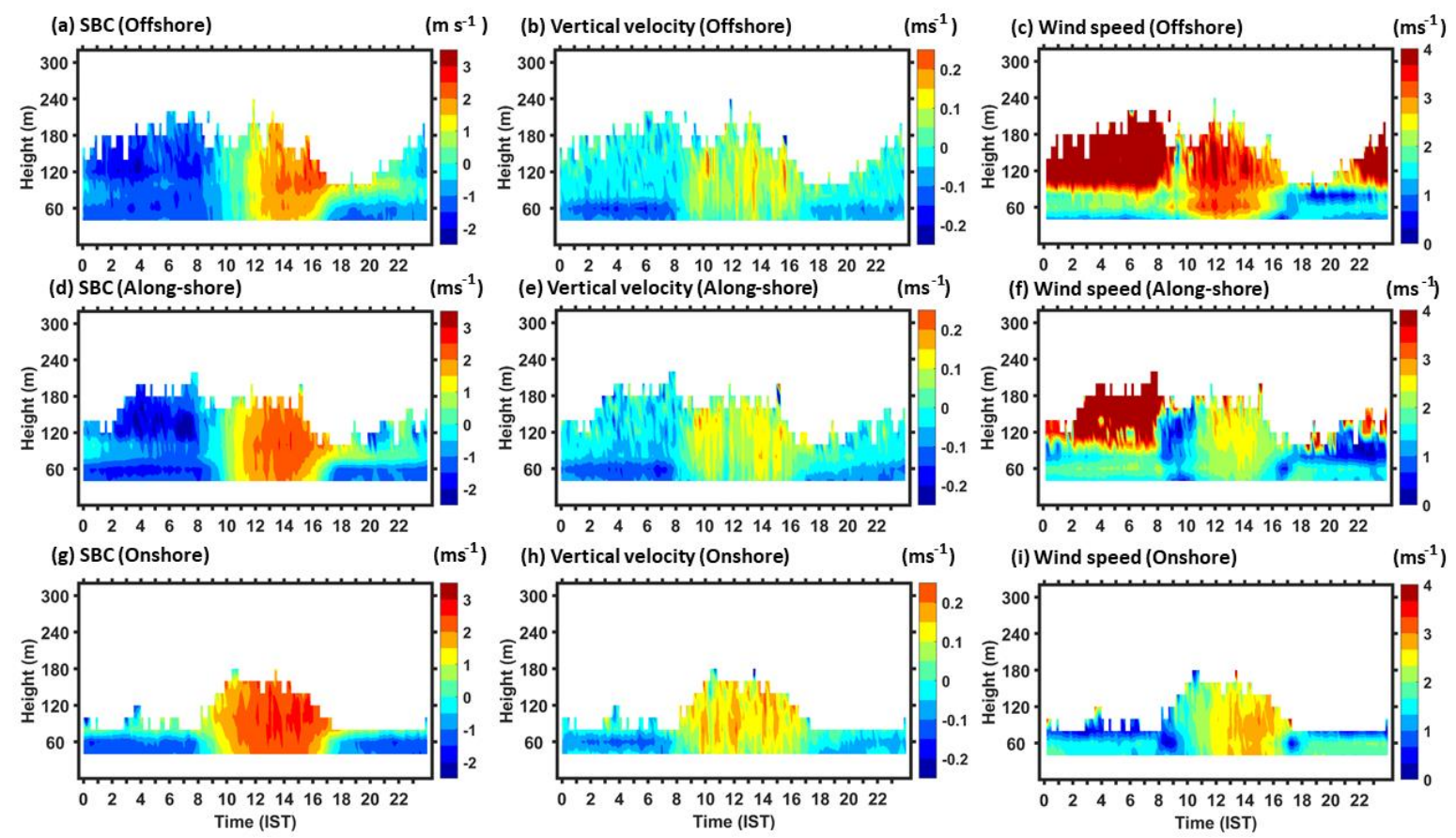

Fig. 10 Time-height cross-sections of sea breeze component $(\mathrm{a}, \mathrm{d}, \mathrm{g})$; vertical velocity $(\mathrm{b}, \mathrm{e}, \mathrm{h})$ and wind speed $(c, f, i)$ observed by Doppler sodar observations under the influence of offshore (top panel), along-shore (middle panel) and onshore (bottom panel) during winter 2011-12 
Table 1 Specifications of the Doppler sodar

\begin{tabular}{|l|l|}
\hline Operating Frequency & $1700 \mathrm{~Hz}$ to $2500 \mathrm{~Hz}$ \\
\hline No. of elements & $52(8 \times 8)$ \\
\hline Acoustic Power & $100 \mathrm{~W}$ \\
\hline No. of beams & 3 (zenith, north, east) \\
\hline Beam angle & $16^{\circ}$ \\
\hline Pulse width & Programmable \\
\hline Pulse repetitive frequency & Programmable \\
\hline Averaging Time & $1-60$ min \\
\hline No. of FFT & 4096 \\
\hline Transmission type & Reflecting mode \\
\hline Beamwidth & 5 \\
\hline Wind Direction & $0-360$ degree \\
\hline Wind Speed & $0-30 \mathrm{~m} \mathrm{~s}^{-1}$ \\
\hline Wind Speed Accuracy & $0.1 \mathrm{~m} \mathrm{~s}^{-1}$ \\
\hline Minimum Height & $20 \mathrm{~m}$ \\
\hline Maximum Height & $1 \mathrm{~km}$ \\
\hline Data Products & $\begin{array}{l}\text { Wind components, echogram, time- } \\
\text { height plot, wind rose and wind } \\
\text { statistics }\end{array}$ \\
\hline
\end{tabular}

696

697 


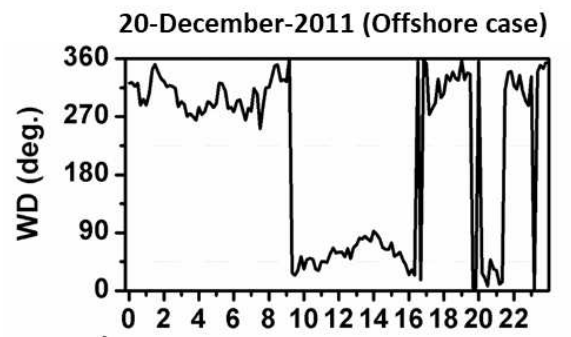

04-February-2012 (Alongshore case) 10-January-2012 (Onshore case)
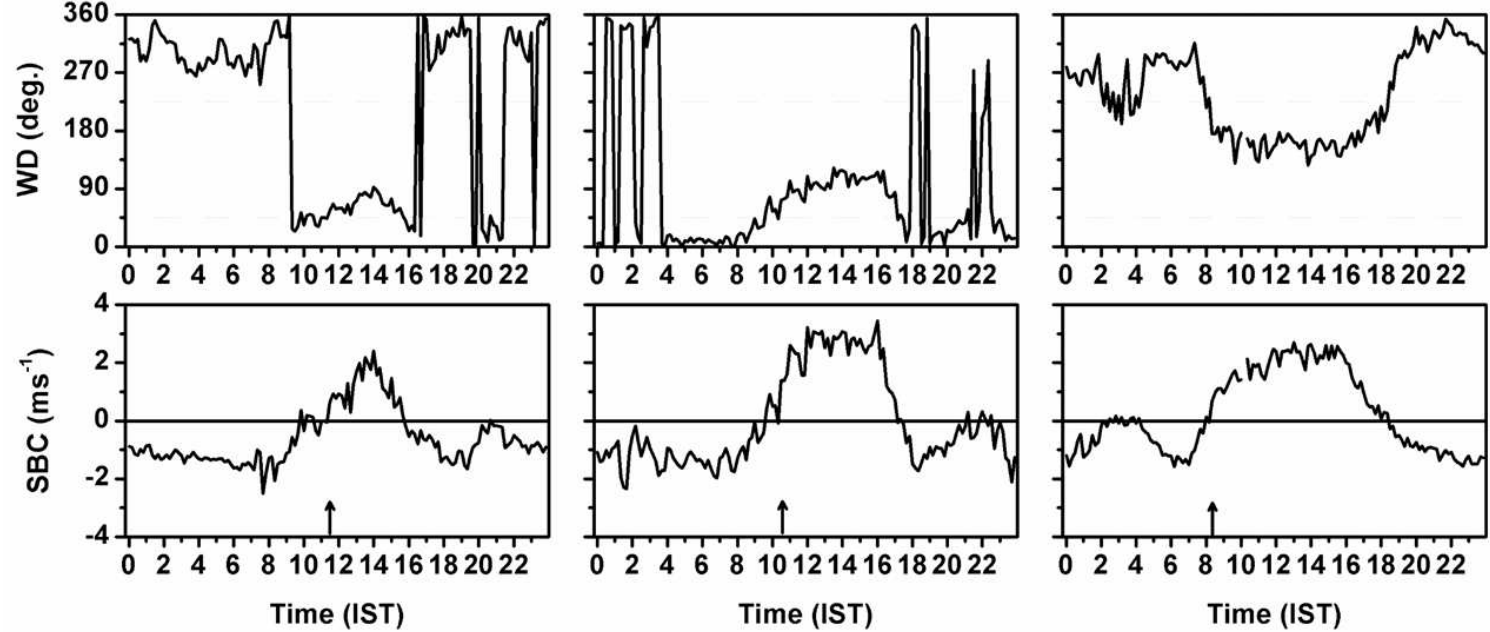

Fig. S1 Diurnal variations of wind direction (Top panel) and sea breeze component (bottom panel) observed at $60 \mathrm{~m}$ from the Doppler sodar observations on 20 December 2011, 04 February 2012 and 10 January 2012 representative days for offshore wind, along-shore wind and onshore wind cases respectively. The upward arrow marked in the bottom panel represents the time of onset of the sea breeze 

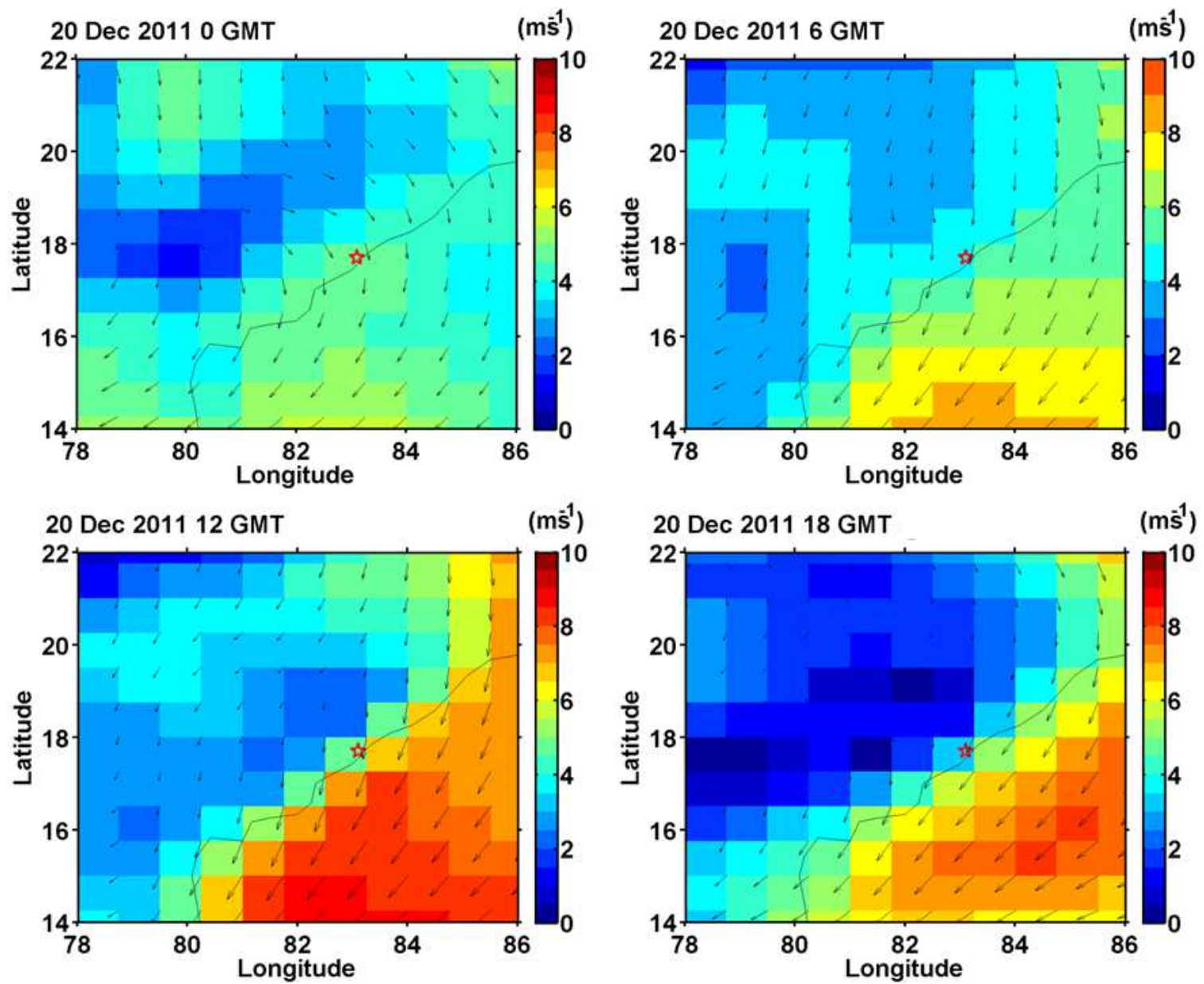

Fig. S2 Synoptic circulation pattern at $0,6,12$ and 18 GMT $(0530,1130,1730$ and 2330 IST at Visakhapatnam) on 20 December 2011, obtained from the ERA Interim reanalysis data. 

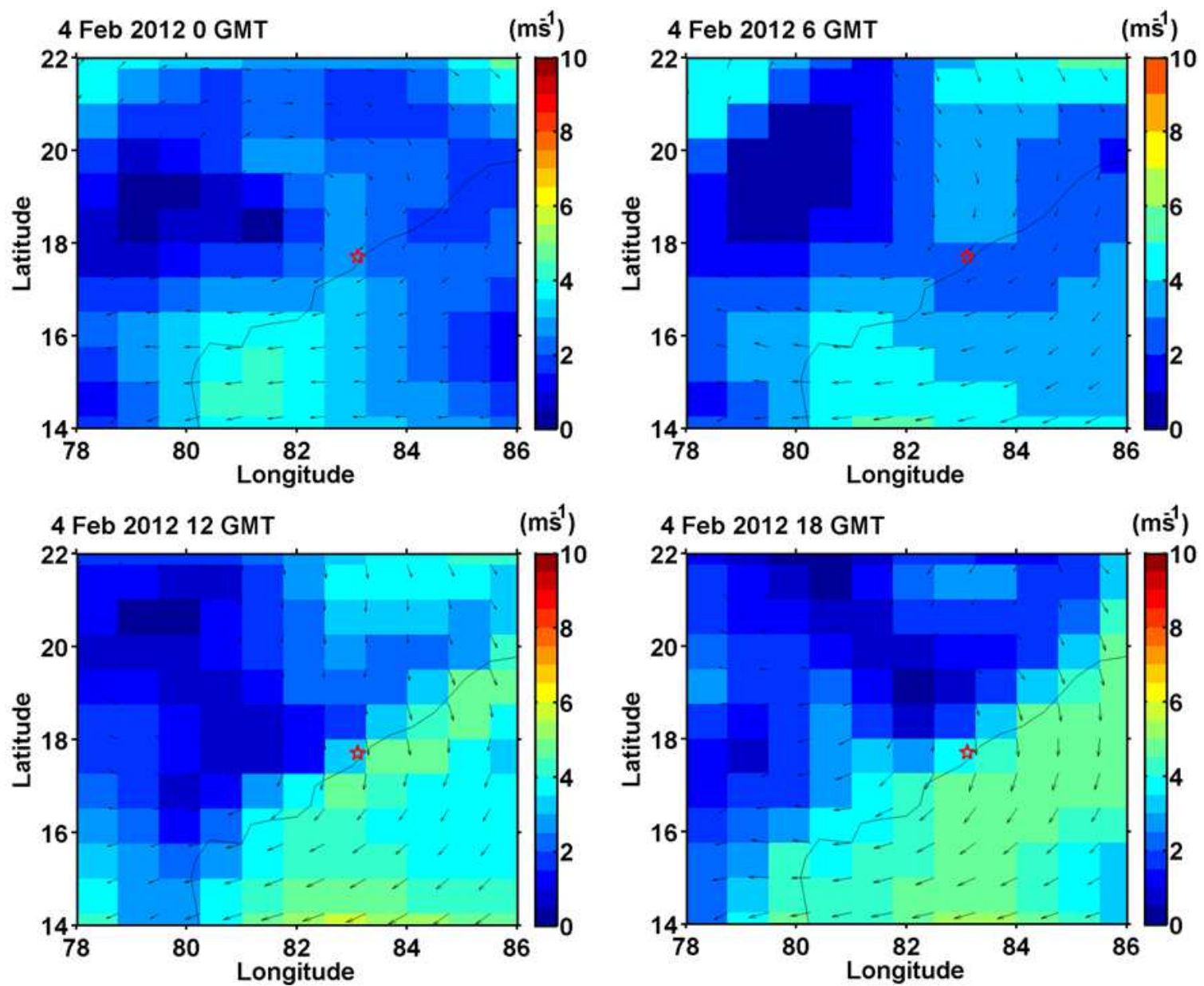

Fig. S3 Synoptic circulation pattern at 0, 6, 12 and 18 GMT $(0530,1130,1730$ and 2330 IST at Visakhapatnam) on 4 February 2012, obtained from the ERA-Interim reanalysis data. 

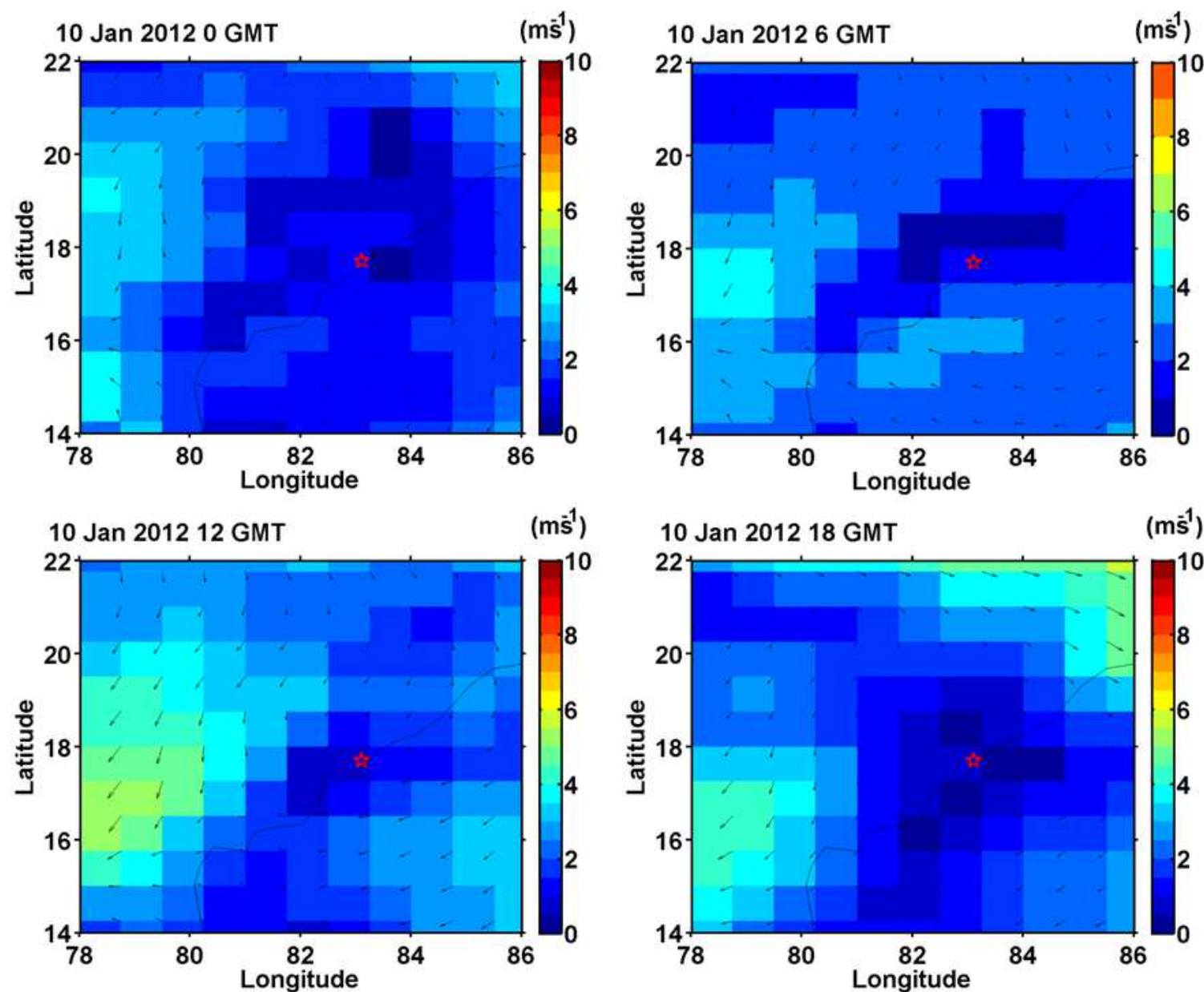

Fig. S4 Synoptic circulation pattern at 0, 6, 12 and 18 GMT $(0530,1130,1730$ and 2330 IST at Visakhapatnam) on 10 January 2012, obtained from the ERA-Interim reanalysis data. 